경부혈관 초음파 표준검사지침. 2부 - 임상적 유용성

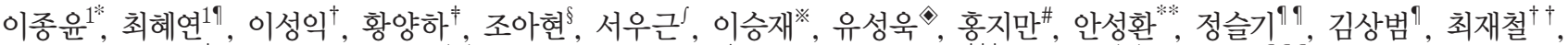

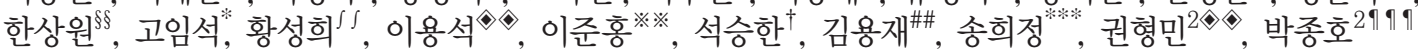

국립중앙의료원 신경과, 강동경희대병원 신경과", 원광대학교 의과대학 산본병원 신경과 ${ }^{\dagger}$, 경북대학교병원 신경과 ${ }^{\dagger}$, 가톨릭대학교 여의도성모병원 신경과\$, 성균관대학교 의과대학 삼성서울병원 신경과, 순천향대학교 의과대학 부천병원 신경과*, 고려대학교 의과대학 안암병원 신경과 , 아주대학교병원 신경과\#, 조선대학교병원 신경과 *, 정슬기신경과의원 ${ }^{n}$, 제주대학교병원 신경과 ${ }^{\dagger}$, 인제대학교 상계백병원 신경과 $\$$, 한림대학교 강남성심병원 신경과 보라매병원 신경과 , 국민건강보험공단 일산병원 신경과**, 이화여자대학교 목동병원 신경과\#, 충남대학교병원 신경과***, 한양대학교 명지병원 신경과 191

\title{
Extracranial Carotid Duplex Ultrasonography. Part II - Clinical Utility of Carotid Duplex Ultrasound
}

Jong Yun Lee ${ }^{1^{\star}}$, Hye-Yeon Choi ${ }^{1}$, Sung Ik Lee ${ }^{\dagger}$, Yang-Ha Hwang ${ }^{\ddagger}$, A-Hyun Cho ${ }^{\S}$, Woo-Keun Seo', Seung-Jae Lee*, Sungwook $\mathrm{Yu}^{\star}$, Ji Man Hong\#, Seong Hwan $\mathrm{Ahn}^{* *}$, Seul-Ki Jeong IீI, Sang-Beom Kim ,

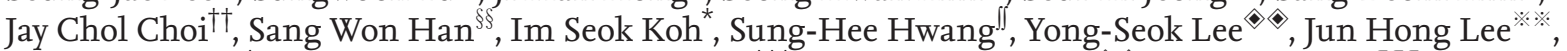

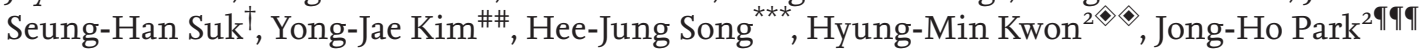

Departments of Neurology, National Medical Center ${ }^{\star}$, Kyung Hee University Hospital at Gangdong", Wonkwang University College of Medicine ${ }^{\dagger}$, Kyungpook National University College of Medicine ${ }^{\ddagger}$, Catholic University of Korea Yeouido St. Mary’s Hospital ${ }^{\S}$, Samsung Medical Center,

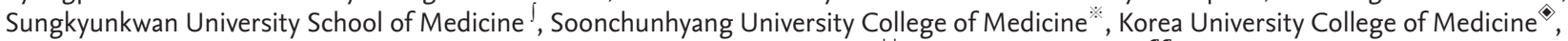

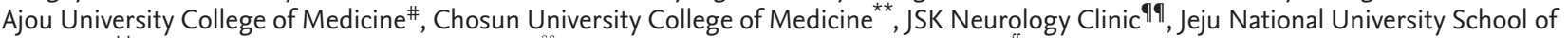
Medicine ${ }^{\dagger \dagger}$, Inje University College of Medicine ${ }^{\S \S}$, Hallym University College of Medicine $\int$, Seoul Metropolitan Government-Seoul National University Boramae Medical Center ${ }^{\star}$, Ilsan Hospital, National Health Insurance Service ** , Ehwa Women's University College of Medicine ${ }^{\# \#, ~}$

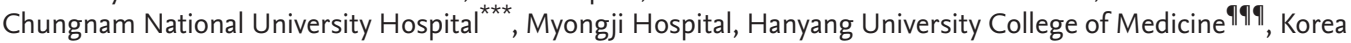

Carotid duplex ultrasonography (CDU) is noninvasive and easy to use for evaluation of various carotid artery diseases. Carotid atherosclerosis is a major indication for CDU. CDU can determine the degree of stenosis, plaque characteristics, and intima-media thickness for evaluation and estimation of carotid atherosclerosis, and can be used as a screening and follow-up tool after carotid revascularization. Here, we summarize the clinical indications and utility of CDU based on established evidence. The main topics include: 1) Evaluation and management of symptomatic and asymptomatic carotid atherosclerotic stenosis; 2) surveillance after carotid artery revascularization; 3 ) screening for cardiovascular risk; 4) perioperative evaluation; 5) evaluation of other diseases including cervical artery dissection, temporal arteritis, Takayasu's disease, and subclavian artery steal syndrome; and 6) diagnosis of dizziness, vertigo, and syncope. This special review will discuss rational indications and utility of CDU, and will be of interest to clinicians who provide care for patients with various extracranial carotid/vertebral artery diseases.

\section{J Neurosonol Neuroimag 201\$;10(2):61-79}

Key Words: Carotid duplex ultrasonography; Clinical indication; Clinical utility

${ }^{1}$ Jong Yun Lee and Hye-Yeon Choi contributed equally to this work as first author.

${ }^{2}$ Jong-Ho Park and Hyung-Min Kwon contributed equally to this work as corresponding author.
Received: September 21, 2018 Revised: October 26, 2018 Accepted: November 20, 2018

Address for correspondence: Jong-Ho Park

Department of Neurology, Myongji Hospital, Hanyang University College of Medicine 55 Hwasu-ro 14beon-gil, Deogyang-gu, Goyang 10475, Korea Tel: $+82-31-810-5460$

Fax: +82-31-969-0500

E-mail:jhpark619@hanyang.ac.kr

Hyung-Min Kwon

Department of Neurology, SMG-SNU Boramae Medical Center, Seoul National University College of Medicine, 20 Boramae-ro 5-gil, Dongjak-gu, Seoul o7061, Korea Tel: $+82-2-870-2475$ Fax: $+82-2-831-2826$ E-mail:hmkwon@snu.ac.kr 


\section{서 론}

경동맥이중초음파(carotid duplex ultrasonography)는 검 사 영역이 국한적이고, 석회화가 심한 경우 평가가 어려운 한 계점이 있으나, 죽상판의 유무뿐 아니라 그 형태도 평가할 수 있는 장점이 있다. 또한, 무엇보다 상대적으로 경제적이며, 안 전한 비침습적 검사로써 경동맥질환을 진단하고 추적하는데 유용한 검사로 많이 활용되고 있다. ${ }^{1}$ 그러나 검사의 대상이 되 는 경동맥질환 및 검사의 유용성에 대하여 아직까지 체계적으 로 정립되어 있지 않다.

대한신경초음파학회에서는 2016년에 경두개도플러초음 파 검사의 기준을 마련하기 위하여 가이드라인을 제시한바 있 다. ${ }^{2,3}$ 이번에는 경동맥이중초음파검사의 가이드라인으로 마련 하고자 1 부에서 경동맥과 경정맥 초음파의 기본 원리 및 표준 검사 방법을 제시하였고, 본 2 부에서는 폭넓은 문헌고찰을 통 하여 임상에서 경동맥이중초음파가 필요한 질환, 검사의 유용 성 그리고 검사 시기 등에 대해서 총괄적으로 다루고자 한다.

\section{경동맥협착}

\section{1. 증후성 경동맥협착}

증후성 경동맥협착(symptomatic carotid stenosis)은 죽상 경화로 인한 내경동맥의 협착으로 인하여 해당 내경동맥의 혈 관영역에서 허혈증상이 발생하는 경우를 의미한다. 경동맥질 환과 연관된 허혈질환으로는 동측 안구의 일과성흑암시 (amaurosis fugax), 중심 또는 가지 망막동맥폐색(central or branch retinal artery occlusion), 허혈시신경병증(ischemic optic neuropathy) 등의 눈 증상 혹은 다양한 대뇌반구 증상 을 동반한 뇌경색 혹은 일과성 허혈발작(transient ischemic attack)이 포함된다. 증후성 경동맥협착이 있는 환자에서 뇌 졸중의 재발 위험도는 연간 약 8-13\%로 알려져 있으며, 무증
상성 경동맥협착이 $50 \%$ 이상인 경우 이로 인하여 추후 발병 하는 뇌경색이 전체 뇌경색 환자의 약 7- $15 \%$ 에 이른다. ${ }^{4,5}$ 경 동맥협착이 뇌경색을 유발하는 기전은 죽상경화판에서 발생 한 혈전에 의한 동맥-동맥 색전, 죽상경화판에서 기인한 콜레 스테롤 크리스탈 등에 의한 색전, 두개외혈관의 죽상경화판의 파열로 인한 급성 폐색, 두개외혈관의 박리나 내피내혈전, 협 착에 의한 뇌관류 저하 등이 제시되고 있다. ${ }^{6}$ 증후성 경동맥협 착은 적극적인 치료를 할 경우에도 증상 재발률이 높다고 알 려져 있다. 내과적 치료와 경동맥내막절제술을 비교한 European Carotid Surgery Trial (ECST) 연구에서는 3년이 경과 할 때까지 내과적 치료군에서는 약 $25.9 \%$ 에서, 경동맥내막절 제술을 시행할 경우에는 약 $14.9 \%$ 에서 뇌졸중이 재발하였고, ${ }^{7}$ North American Symptomatic Carotid Endarterectomy Trial (NASCET)에서는 내과적 치료만 시행한 경우 3-5년이 경과할 때 약 $25 \%$ 의 환자에서, 경동맥내막절제술을 시행한 경 우에는 약 10-15\%에서 뇌경색이 재발하였다. ${ }^{8}$ 이와 같은 높 은 재발률은 최근의 연구에서는 다소 감소하고 있는데, 경동 맥내막절제술과 경동맥스텐트삽입술을 비교한 International Carotid Stenting Study (ICSS)의 장기간 연구에서는 경동맥 내막절제술 혹은 경동맥스텐트삽입술을 시행한 경우 5 년 재발 률이 각각 약 $9.4 \%$ 및 $15.2 \%$ 였다. ${ }^{9}$

1) 증후성 경동맥협착증에서의 경동맥이중초음파검사의 유 용성

(1) 협착 정도의 진단

경동맥협착을 평가하는 방법으로는 NASCET법과 ECST법 이 있으나, 수술 및 시술을 결정할 때 주로 NASCET법을 사 용하고 있다. 증후성 경동맥협착증에서의 협착 정도를 초음 파를 통하여 평가한 연구에 따르면, 내경동맥의 최고수축기 속도(peak systolic velocity) $210 \mathrm{~cm} / \mathrm{sec}$ 를 기준으로 하였 을 때 민감도 $94 \%$, 특이도 $77 \%$, 양성예측도 $68 \%$, 음성예측 도 $96 \%$ 및 정확도 $83 \%$ 로 $70 \%$ 이상의 협착을 진단할 수 있

TABLE 1. Parameters used in carotid Duplex ultrasound for estimating the degree of carotid artery stenosis ${ }^{11}$

\begin{tabular}{|c|c|c|c|c|}
\hline \multirow{2}{*}{ Degree of stenosis*, \% } & \multicolumn{2}{|c|}{ Primary parameters } & \multicolumn{2}{|c|}{ Additional parameters } \\
\hline & ICA PSV, $\mathrm{cm} / \mathrm{s}$ & Plaque estimate ${ }^{\dagger}, \%$ & ICA/CCA PSV ratio & ICA EDV, $\mathrm{cm} / \mathrm{s}$ \\
\hline Normal & $<125$ & None & $<2.0$ & $<40$ \\
\hline$<50$ & $<125$ & $<50$ & $<2.0$ & $<40$ \\
\hline 50 to 69 & 125 to 230 & $\geq 50$ & 2.0 to 4.0 & 40 to 100 \\
\hline$\geq 70$ but less than near occlusion & $>230$ & $\geq 50$ & $>4.0$ & $>100$ \\
\hline Near occlusion & High, low, or undetectable & Visible & Variable & Variable \\
\hline Total occlusion & Undetectable & Visible, no detectable lumen & Not applicable & Not applicable \\
\hline
\end{tabular}

ICA; internal carotid artery, CCA; common carotid artery, PSV; peak systolic velocity, EDV; end-diastolic velocity.

*Based on conventional angiography.

†Plaque estimate (diameter reduction) with gray-scale and color Doppler ultrasound. 
다. ${ }^{10}$ 하지만 대부분의 경동맥 초음파검사실에서는 Society of Radiologists in Ultrasound에서 제시한 consensus criteria 를 사용하고 있다(Table 1). ${ }^{11}$ 이 기준에서는 내경동맥의 최고 수축기속도를 기반으로 죽상경화판의 유무, 확장말기속도(end diastolic velocity), 내경동맥과 총경동맥의 최고수축기속도 의 비 등을 종합하여 경동맥협착을 $<50 \%, 50-69 \%, \geq 70 \%$ 및 완전폐색으로 진단하도록 권장하고 있으며, 대부분의 연구 에서 이 기준에 따라 수술 및 시술을 결정하고 있다. 미국의 경우 경동맥내막절제술을 받는 환자들의 $80 \%$ 에서 수술 전 평 가 도구로 경동맥이중초음파가 주로 이용되고 있다. ${ }^{11}$ 비침습 적인 검사인 경동맥 초음파, 자기공명혈관조영술(MR Angiography) 및 CT혈관조영술의 진단적 가치를 비교한 메타 연 구에서는 경동맥 초음파검사가 다른 비침습적인 검사들에 비 하여 비슷한 정도의 정확도를 보이며, 특히 70-99\%의 협착은 $84 \%, 50-69 \%$ 의 협착은 $91 \%$ 로 높은 특이도를 보였다. ${ }^{12}$ 하지 만 경동맥협착 $60 \%$ 이상에서는 경동맥이중초음파의 특이도가 $68-86 \%$ 이므로 ${ }^{13}$ 경동맥내막절제술이 필요할 것으로 판단될 경우 불필요한 수술을 시행할 오류를 최소화하기 위하여 조영 증강 자기공명혈관조영술(contrast-enhanced MRA)을 고려 해야 하고 자기공명혈관조영술에서도 결론을 내지 못할 경우 $\mathrm{CT}$ 혈관조영술이 판정에 도움이 될 것이다. ${ }^{14}$ 따라서, 수술이 나 시술의 결정에 있어서는 자기공명혈관조영술, CT혈관조영 술을 병행하여 검사하거나 혹은 다른 검사자가 경동맥 초음파 를 재검할 것을 권고한다. ${ }^{1,12}$

\section{(2) 경동맥재개통술의 합병증 예측}

경동맥이중초음파는 경동맥내막절제술 혹은 경동맥스텐트 삽입술 등의 재개통술 과정에서 발생할 수 있는 다양한 합병증 을 예측하는데 유용하게 사용될 수 있다. 212 명의 환자에서 이 루어진 228예의 경동맥스텐트삽입술의 시행 결과를 분석한 연 구에서 시술 전 시행한 경동맥 초음파의 회색조중앙값(gray scale median, GSM)은 시술 전후의 합병증이 발생한 군과 발 생하지 않은 군 사이에 유의한 차이를 보였다. 또한 $\mathrm{GSM}$ 은 향 후 재협착 병변에서 낮은 결과를 보여주었다. ${ }^{15}$ 경동맥스텐트 삽입술의 경우 죽상판을 제거하지 않고 혈관벽 측면으로 밀어 내는 과정이므로 경동맥 초음파는 죽상판의 형태를 파악하는 데 중요한 정보를 줄 수 있다. 즉, 죽상판의 표면(매끄러운지, 불규칙한지)과 구조(균질한지, 비균질한지, 출혈동반 여부, 석 회화 여부, 에코음영 정도)에 대한 정보를 통하여 뇌졸중 발 생에 대한 위험도를 제시해 준다. 실제로 다기관 Imaging in Carotid Angioplasty and Risk of Stroke (ICAROS) 연구에 서 뇌혈관조영술을 통한 경동맥스텐트삽입술 시행에 앞서 경 동맥초음파에서 무에코(echolucent) 죽상판을 보일 경우 시술 중 뇌졸중 발생과 높은 연관성을 보여 주었다. ${ }^{16}$

하지만 경동맥이중초음파는 선별검사용으로 수술적 치료를 결정할 만큼 위험도를 측정하지는 못한다. 왜냐하면 검사에 죽
상판 형태 분석이 기본적으로 시행되는 것이 아닐 뿐만 아니라 이러한 분석을 통한 표준화된 데이터가 없기 때문이다. 또 다 른 단점으로 대뇌관류를 측정할 수 없고, 뇌내 측부순환이나 동맥류같은 혈관 모양의 정보는 제공하지 못한다.

(3) 경동맥재개통술 이후 추적검사

경동맥내막절제술이나 경동맥스텐트삽입술 등의 경동맥재 개통술을 시행한 경우에는 경동맥 초음파에서 혈류속도가 빠 르게 측정될 수 있어 해석에 주의가 필요하다. 경동맥내막절제 술을 시행한 경우 시술 부위의 혈관은 상당히 넓어지지만, 원 위부 혈관은 좁은 채로 남아있어 국소적인 혈류속도가 빠르게 측정될 수 있고, 특히 수술 중 협착 부위에 인조혈관을 이용한 재개통술을 시행할 경우 이러한 소견이 크게 나타난다. ${ }^{17}$ 경동 맥스텐트삽입술의 경우에도 스텐트에 의하여 경동맥의 경화도 가 증가함에 따라서 이 부위를 지나는 혈류의 속도가 증가하는 경향을 보일 수 있다. ${ }^{18}$

아직까지 경동맥재개통술 이후에 경동맥이중초음파검사 소 견에 대한 적절한 해석기준은 확립되어 있지는 않다. 다만, 여 러 연구에서 $50 \%$ 의 협착을 예측하는 기준으로 내경동맥의 최 고수축기속도 150-224 cm/sec 정도로 보고하고 있으며, ${ }^{19-21}$ 각 검사실에서는 그 검사실의 기준을 설정하고 이를 정기적으 로 검증하는 과정이 필요하다. 종래에 9 개의 임상시험 결과를 체계분석한 결과에 따르면, 시술 후 경동맥 초음파를 시행하는 시기는 시술 직후보다는 약 1년 정도 경과한 후에 시행하는 것 이 더 다양한 정보를 제공하는 것으로 알려졌다. ${ }^{22}$

\section{(1) 경동맥스텐트삽입술 후 추적검사}

경동맥스텐트삽입술 후 스텐트내재협착(in-stent restenosis)은 흔히 발생하는 것으로 알려져 있으며, 시술 5년 내 $80 \%$ 이상으로 진행하는 경우는 $6.4 \%$ 이다. ${ }^{23}$ 이러한 가능성을 확인하고 뇌졸중 재발방지를 위한 감시를 위해서 경동맥초음 파의 활용이 필요하다. 하지만 스텐트가 삽입된 경동맥은 혈류 와 혈관탄성(compliance)이 변화되어 협착 정도가 과평가될 소지가 있다. ${ }^{16,18-20,24,25}$ 이러한 문제를 보완하기 위하여 경동 맥스텐트삽입술을 받은 경동맥의 스텐트내재협착에 대한 추적 관찰에 적용할 수정혈류속도 기준임계치(modified velocity criteria thresholds)가 제시되었다(Table 2). ${ }^{20,26}$ 스텐트내재 협착을 모니터하기 위하여 경동맥스텐트삽입술 이후 퇴원 전, 3 개월 후, 이후로는 6 개월 간격으로 3 회 경동맥 초음파검사를 시행하도록 하며, 2 년 동안 스텐트내재협착이 없을 경우에는 이후 1 년마다 평가할 것을 권장한다. ${ }^{27}$

\section{(2) 경동맥내막절제술 후 추적검사}

경동맥내막절제술 후 재협착은 1-37\%까지 보고되었 지만 뇌졸중재발을 보인 경우는 $8 \%$ 미만이다. ${ }^{28-30}$ 경동 맥내막절제술 후 경동맥 초음파를 통한 추적검사를 얼마 
Lee JY and Choi HY, et al. Clinical Utility of Carotid Duplex Ultrasound

TABLE 2. Two modified criteria for diagnosis of in-stent restenosis after carotid artery stenting

\begin{tabular}{|c|c|c|c|c|c|}
\hline \multicolumn{3}{|c|}{ AbuRahma et al. ${ }^{20}$} & \multicolumn{3}{|c|}{ Lal et al. ${ }^{26}$} \\
\hline Stenosis*, \% & $\mathrm{PSV}, \mathrm{cm} / \mathrm{s}$ & ICA/CCA ratio & Stenosis*, \% & $\mathrm{PSV}, \mathrm{cm} / \mathrm{s}$ & ICA/CCA ratio \\
\hline o to 29 & $<154$ & $<1.5$ & o to 19 & $<150$ & $<2.15$ \\
\hline 30 to 49 & 154 to 223 & & 20 to 49 & 150 to 219 & \\
\hline 50 to 79 & 224 to 324 & $\geq 3.4$ & 50 to 79 & 220 to 339 & $\geq 2.7$ \\
\hline 80 to 99 & $>325$ & $\geq 4.5$ & 80 to 99 & $>340$ & $\geq 4.15$ \\
\hline
\end{tabular}

ICA; internal carotid artery, CCA; common carotid artery, PSV; peak systolic velocity.

*Based on conventional angiography.

나 해야 하는지는 아직까지 의견이 분분하다. 수술 부위 를 일차봉합(primary closure)하는 경우보다 부분혈관 성형(patch angioplasty)을 거친 경우 재협착이 더 적 다고 알려져 있다. ${ }^{31}$ 따라서 일차봉합을 한 경우 경동맥 초음파검사 추적검사는 1 개월, 6 개월, 이후 1년마다 시 행할 것을 권고하고 있고, ${ }^{32}$ 부분혈관성형의 경우 6 개 월째 추적검사에서 정상일 때에는 정기적인 추적검사가 권장 되지 않는다. ${ }^{33}$

(4) 회색조중앙값(grey-scale median, GSM)

앞에 기술한 바와 같이 경동맥 초음파에서 GSM이 낮은 경우 나, 스텐트삽입술 후 최고수축기속도가 $120 \mathrm{~cm} / \mathrm{sec}$ 이상으로 증가를 보일 경우 재협착이 잘 발생하는 것으로 알려져 있어 경동맥 초음파는 혈관의 협착 정도를 측정할 수 있을 뿐 아니라 향후 재협착을 예측하는 데에도 유용하게 사용될 수 있다. ${ }^{15,34}$

\section{2. 무증상 경동맥협착}

무증상 경동맥협착(asymptomatic carotid artery steno$\mathrm{sis})$ 은 증상 없이 우연히 검사에서 발견되는 협착을 말하며, 협 착 경동맥 영역의 뇌허혈 또는 일과성 허혈 증상을 경험하지 않았거나, 뇌허혈 증상을 경험하였더라도 증상 발생 이후 6 개 월 이상 경과된 환자로 정의할 수 있다. 일반 인구에서 무증상 경동맥협착의 유병률은 2-8\%로 다양하게 보고되었다. ${ }^{35}$ 무증 상 경동맥협착과 연관된 위험인자로는 나이, 성별(남성), 당뇨 병, 대사증후군, 고혈압, 이상지질혈증, 흡연 등이 알려져 있 으며, 나이와 성별이 가장 강력한 위험인자이다. 무증상 경동 맥 협착은 협착의 정도에 따라 허혈뇌졸중 또는 일과성 허혈발 작을 유발할 수 있어 세심한 평가 및 추적관찰이 요구된다.

\section{1) 무증상 경동맥협착증에서 경동맥이중초음파검사의 유용성}

Asymptomatic Carotid Stenosis and Risk of Stroke (ACSRS) 연구는 최대 7년 동안 1,101명의 무증상 경동맥협 착 환자의 자연 경과를 추적 관찰한 대규모 관찰 연구로, 경동
맥협착 정도와 뇌졸중 발생률의 상관관계를 확인할 수 있다. ${ }^{36}$ 이 연구에서는 경동맥협착 정도가 협착 동측 허혈뇌졸중 발생 과 연관이 있음을 확인하였고, 협착 정도에 따라 뇌졸중 발생 위험도를 다음과 같이 분류하였다: (1) 저위험군 $50-79 \%$ 협 착): 연간 뇌졸중 발생위험 1-2\%; (2) 중간위험군(70-89\% 협 착): 연간 뇌졸중 발생위험 2-4\%; (3) 고위험군(90-99\%): 연 간 뇌졸중 발생위험 4-6\%. 이러한 뇌졸중 발생의 위험은 시 간이 지나더라도 사라지지 않으며, 약 $20 \%$ 정도의 무증상 경 동맥협착 환자들은 추적검사에서 협착 정도가 진행하는 것으 로 보고되었다. ${ }^{37}$ 특히, 무증상 경동맥협착의 정도가 $80 \%$ 이 상으로 진행하는 경우 진행하지 않는 경우에 비하여, 일과성 허혈발작 또는 허혈뇌졸중 위험이 약 3 배 증가하는 것으로 보 고되었다. ${ }^{37}$ 상기 결과들을 종합해보면 무증상 경동맥협착이 $80 \%$ 이상인 경우에는 뇌졸중 위험성이 증가되어 경동맥내막 절제술이나 경동맥스텐트삽입술과 같은 경동맥재개통술의 대 상이 될 수 있다.

무증상 경동맥협착 환자에서 경동맥 초음파의 $\mathrm{B}$ 방식 영상 을 통한 죽상경화판의 에코 성상 또한 뇌졸중 발생의 위험을 가늠할 수 있는 방법으로 인자로 알려져 있다. 무에코 또는 저 에코 경화판(echolucent or hypoechoic plaque)은 조직학적 으로 지방질이 풍부하고 괴사조직을 포함하며 또한 죽상판내 출혈(intraplaque hemorrhage)을 시사하는 소견으로, 죽상 판의 불안정성(plaque instability)과 연관된다. 고에코죽상판 (echodence or hyperechoic plaque)은 지방질에 비하여 칼 슘침착이 높으며 죽상판의 안정성(plaque stability)과 연관되 어, 주로 오랜 기간 동안 증상이 없는 무증상 경동맥협착 환자 들에서 관찰된다. ${ }^{35}$ 무증상 일반인을 대상으로 평균 3 년간 추 적 관찰한 Cardiovascular Health 연구에 의하면 저에코 죽 상경화판은 약 2 배 가량 뇌졸중 발생위험을 증가시키고, 경동 맥협착이 $50 \%$ 이상이고 저에코 죽상경화판이 동반된 경우에 는 약 2.3 배 뇌졸중 위험이 증가하는 것으로 보고하였다. ${ }^{38}$

2014년 미국질병예방국특별조사단(United States Preventive Services Task Force, USPSTF)에서 무증상 경동맥 죽상경화는 건강한 성인인구에서 뇌졸중으로 발병하는 경우 가 적기 때문에 경동맥 초음파의 선별검사는 권장하지 않고 있 
다. ${ }^{39}$ 하지만 죽상경화증에 관한 위험인자(예, 나이, 흡연, 고 혈압, 당뇨)를 적어도 2 개 이상 가지고 있거나 관상동맥질환이 나 말초혈관질환 진단을 받은 경우 경동맥협착에 대한 선별검 사를 권장할 수 있다. ${ }^{32}$

\section{경동맥죽상경화증}

과거에는 경동맥죽상경화판의 치료기준을 임상증상이 유발 된 병소이면서 혈관내강의 협착이 큰 경우로 정하였지만, 최근 에는 대뇌관류(perfusion), 죽상판의 형태(plaque morphology), 뇌내측부순환(intracranial collateralization) 상태를 고려하여 위험도를 측정하고 치료원칙을 정하고 있다.

지질핵심(lipid core)이 크고, 얇은 섬유성덮개(fibrous cap)를 갖는 경우 파열하기 쉬운 죽상판(vulnerable plaque) 의 특징적 소견으로 ${ }^{40}$ 특히 큰포식세포(macrophage)와 세포 외지질 성분의 지질이 $40 \%$ 이상을 차지하고 민무늬근육세포 (smooth muscle cell)와 아교질(collagen)로 구성된 섬유근 육요소(fibromuscular component)가 보일 경우 불안정죽상 판으로 정의되는데, ${ }^{41}$ 이는 뇌졸중을 초래할 위험이 높기 때문 에 적극적인 치료 대상이 된다.

\section{심혈관질환의 위험도 예측}

\section{1. 경동맥 내중막두께}

경동맥 초음파를 통하여 B방식으로 내중막두께(intima-media thickness, IMT)와 경동맥죽상판(carotid plaque)을 측정하는 것은 무증상 혈관질환과 심뇌혈관질환 위 험을 평가하는 방법으로 입증된, 비침습적이고 민감도가 높으 며 재현 가능한 검사법이다. 기존 가이드라인에서 경동맥 내 중막두께는 관상동맥심장질환 위험을 평가하는데 도움이 되는 것으로 언급되었다. ${ }^{42,43}$ 무증상 환자의 경동맥 내중막두께와 심혈관질환 위험도를 평가하였을 때, 경동맥 내중막두께가 심 근경색, 뇌졸중, 심혈관 사망 각각 및 전체 조합과 유의한 연 관성을 보였다. 이러한 경동맥 내중막두께의 위험도 예측 능력 은 다른 전통적 위험인자와는 독립적이었다. 2010년 American Heart Association/American College of Cardiology (AHA/ACC) 가이드라인에서는, 중등도의 심혈관질환 위험을 가진 무증상 성인에서 심혈관질환 위험도를 평가할 때 관상동 맥칼슘 점수(coronary calcium score)와 함께 경동맥 내중막 두께를 측정할 것을 권유하였다. ${ }^{44}$

경동맥 내중막두께와 심혈관질환 위험에 관한 연구 결과들 을 Table 3에 요약하였다. 대부분의 연구에서 경동맥 내중막 두께는 심근경색, 뇌졸중, 관상동맥질환 사망, 그 조합의 위험

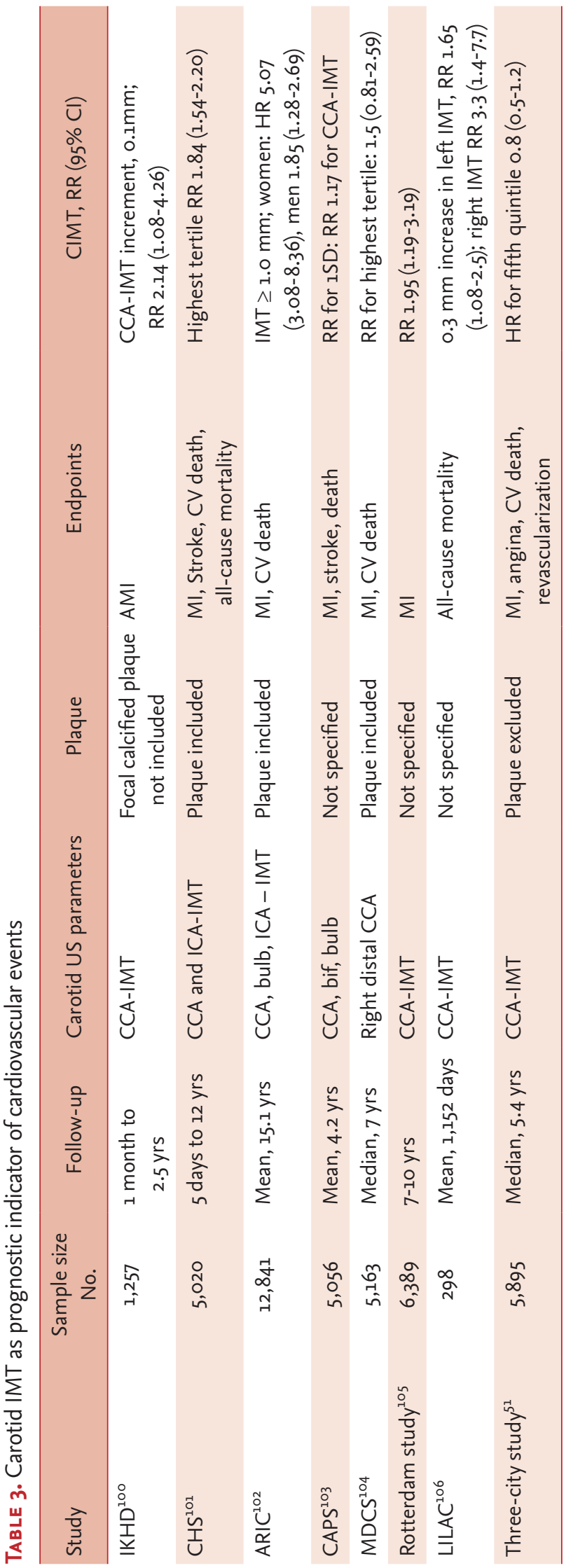




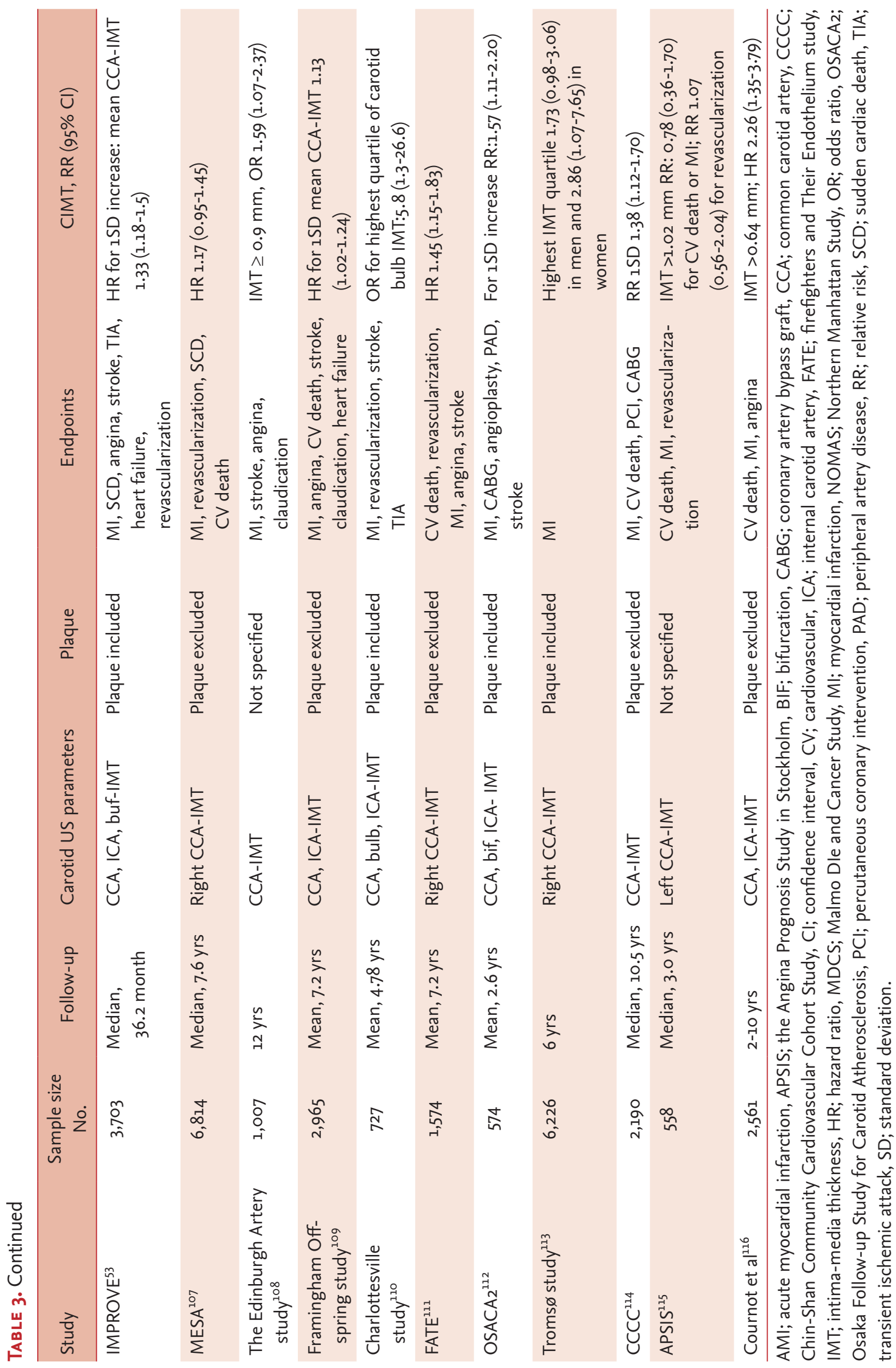


을 증가시켰고 심혈관질환 위험인자, 심혈관질환 발생, 죽상경 화의 정도와 유의한 연관성을 보였다. 내중막두께가 증가하였 을 때 보이는 세포 분자변화가 죽상경화의 진행에서도 나타나 기 때문에 내중막두께와 죽상경화증이 연관성은 있지만, 내중 막두께는 무증상 죽상경화증과 동일한 것은 아니다. 특히 죽상 판이 없는 내중막두께 증가는 죽상경화증과 동일하지는 않다. 다시 말해 단순 내중막두께 증가는 무증상혈과질환으로써, 위 험인자이자 심혈관질환의 표지자로 볼 수 있다.

\section{2. 내경동맥 내중막두께와 죽상판}

총경동맥 내중막두께를 측정할 때, 내경동맥 내중막두께, 경 동맥 죽상판을 함께 관찰하게 되며, 심혈관질환의 위험도를 예측할 때 이를 함께 고려해 볼 수 있다. 미국 심초음파협회 (American Society of Echocardiography, ASE) consensus statement에서 총경동맥 내중막두께가 성별, 나이, 인종 을 고려한 75 백분위수보다 두터울 경우를 비정상 소견으로 간 주하지만, ${ }^{45}$ 초음파영상기법이 발전함에 따라 내경동맥 내중 막두께를 측정하기 쉽게 되었고, 연구 결과 내경동맥 내중막두 께가 총경동맥 내중막두께에 비하여 심혈관질환 상대위험도가 보다 높았다. ${ }^{46}$ Mannheim Consensus Report에 의하면 경 동맥 죽상판의 정의는 주변 내중막두께의 $50 \%$ 이상 또는 0.5 $\mathrm{mm}$ 이상 혈관내강으로 튀어나온 국소조직이거나, 또는 내중 막두께가 $1.5 \mathrm{~mm}$ 이상 두터워진 경우를 말한다. ${ }^{47}$

경동맥 죽상판이 심혈관질환의 예측, 예후인자임을 보여 주는 여러 연구들이 있다(Table 4). 11개의 인구집단연구들 (population-based studies)을 메타분석한 결과 경동맥 죽상 판은 경동맥 내중막두께에 비교하여 볼 때 향후 심근경색을 예 측하는데 보다 높은 진단적 정확성을 보였다. ${ }^{48,49}$ 전통적 위 험인자와 죽상판, 평균 경동맥 내중막두께를 함께 고려하였을 때 남성에서 관상동맥심장질환 위험예측 정도가 더 높았다. ${ }^{50}$ 고식적 위험인자, 경동맥 내중막두께, 죽상판이 합쳐진 모델을 고식적 위험인자만을 포함한 모델과 비교할 때 중등도 위험군 에서 net reclassification index (NRI)가 21.7\%, 전체집단에 서 $9.9 \%$ 였다. 이러한 연구는 죽상판을 내중막두께와 함께 고 려할 때 관상동맥심장질환의 발생위험도를 보다 더 잘 예측할 수 있음을 보여준다. ${ }^{50}$ The Three-City Study에 의하면 총경 동맥 내중막두께가 아닌 경동맥 죽상판이 심장질환발생을 예 측하는 독립적인 인자로 밝혀졌다. 한군데 존재하는 경우 $\mathrm{HR}$ 1.5 (1.0 to 2.2), 두 군데 존재할 경우 HR 2.2 (1.6 to 3.1)였 다. 전통적 위험인자에 경동맥 죽상판을 더 고려할 경우 심장 질환 위험 예측도가 더 증가하였다. ${ }^{51}$ The Tromsø study에 서는 경동맥팽대부(carotid bulb)의 내중막두께를 분석에서 뺄 경우에는 내중막두께가 심근경색 예측인자가 아니었고, 내 중막두께가 아닌 경동맥 죽상판이 허혈뇌졸중의 위험인자였 다. 내중막두께의 두터운 정도와 뇌졸중위험도와 연관성이 없
었다. ${ }^{52} \mathrm{IMPROVE}$ study에서는 총경동맥 내중막두께보다 내 경동맥 내중막두께가 관상동맥 또는 심혈관질환을 더 잘 예측 하였다. ${ }^{53}$

\section{3. 심혈관질환 위험을 평가하기 위한 경동맥이중초음파의 적용}

중등도의 심혈관질환 위험을 가진 환자에서 심혈관질환 위 험도를 보다 더 잘 평가하는데 경동맥 내중막두께 측정과 경동 맥 죽상판 측정이 유용하다. 이외에 다음과 같은 환자들도 또 한 심혈관질환 위험을 평가하기 위한 경동맥 초음파검사의 대 상으로 고려된다.

1) 직계가족 중 조기 심혈관질환이 있는 사람,

2) 하나의 확실한 위험인자(예, 유전성이상지질혈증)가 있는 60세 미만 환자,

3) 두 개 이상 위험인자(예, 고혈압, 당뇨병, 조기심혈관질 환 가족력[직계가족], 만성 신장질환, 비만)를 가진 60세 미만 여자.

그러나 이미 알려진 죽상경화성혈관질환이 있거나, 검사 결 과가 치료에 영향을 미치지 않을 때, 또는 단순히 악화나 호전 을 보기 위한 상습적 목적으로 하는 경우에는 추천하지 않는다.

\section{4. 추적검사}

주기적 검사의 필요성은 부족하다. 일반인집단에서 경동맥 내중막두께의 시간에 따른 진행(증가)과 심혈관질환 발생위험 이 연관성이 있는지는 아직 입증되지 않았다. ${ }^{54}$

\section{5. 검사와 임상 예후}

경동맥 내중막두께 측정과 경동맥 죽상판 존재로 위험을 예 측하는 것이 환자의 예후 향상에 도움이 되는가는 아직 연구가 부족하며 관찰 연구가 있을 뿐이다. 또한, 일반인집단에서 경 동맥 내중막두께 진행과 심혈관질환 발생위험이 연관성이 있 는지는 아직 입증되지 않았다. ${ }^{54}$ 경동맥 내중막두께나 경동맥 죽상판을 치료하는 것이 심혈관질환의 예후을 향상시키는지는 아직 확실하지 않다. 다만 METEOR study에서 관상동맥위험 을 가지거나 Framingham risk score가 $10 \%$ 이내로 낮은 평 균 57세인 984명의 중년 성인을 대상으로 rosuvastatin 40 $\mathrm{mg}$ 을 2년 이상 투여하였을 때 경동맥 내중막두께의 증가가 현저히 감소되었다. ${ }^{55}$

\section{수술과 관련된 뇌졸중위험 예측}

수술 후 발생할 수 있는 뇌졸중은 사망률을 높이고 심각한 


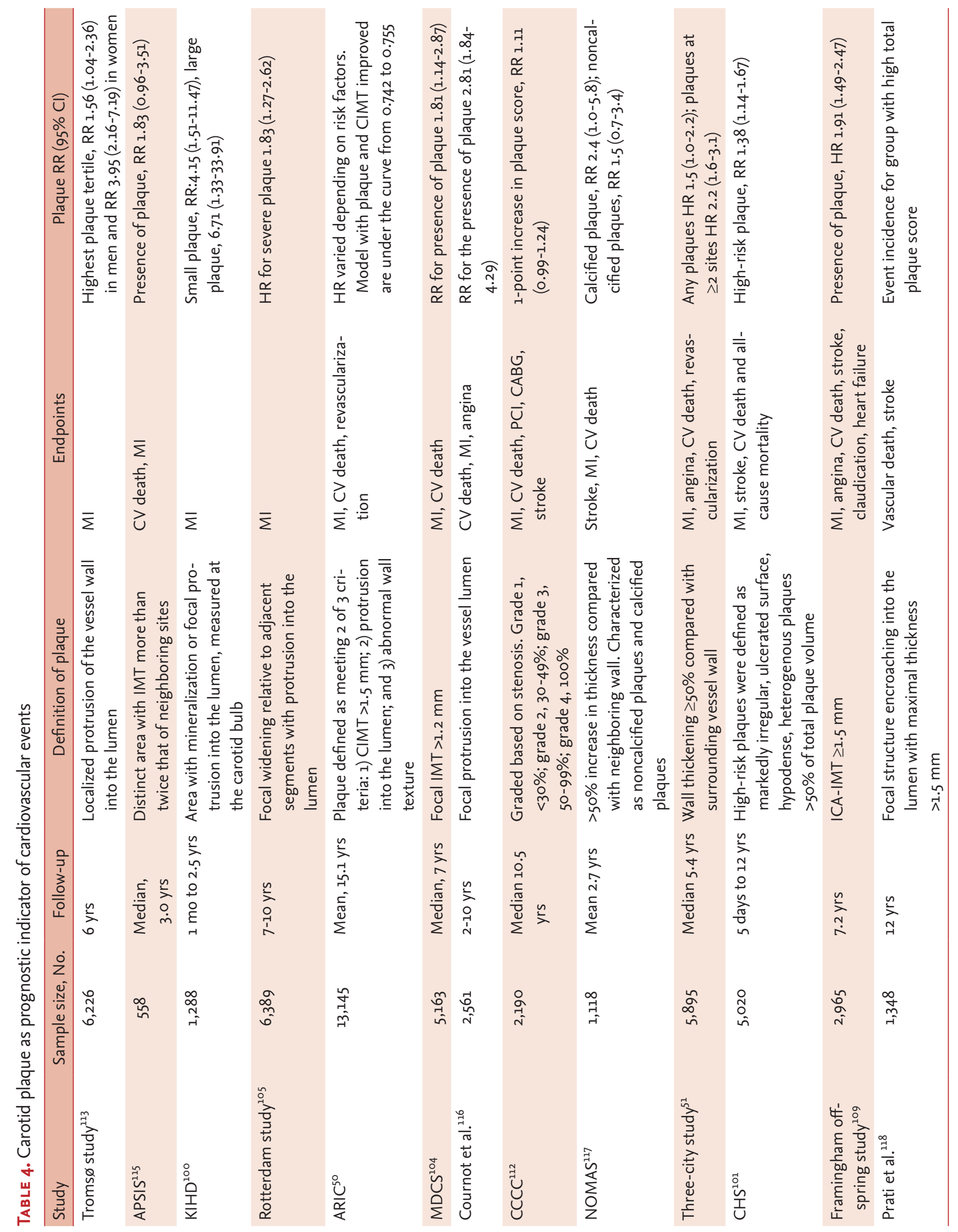




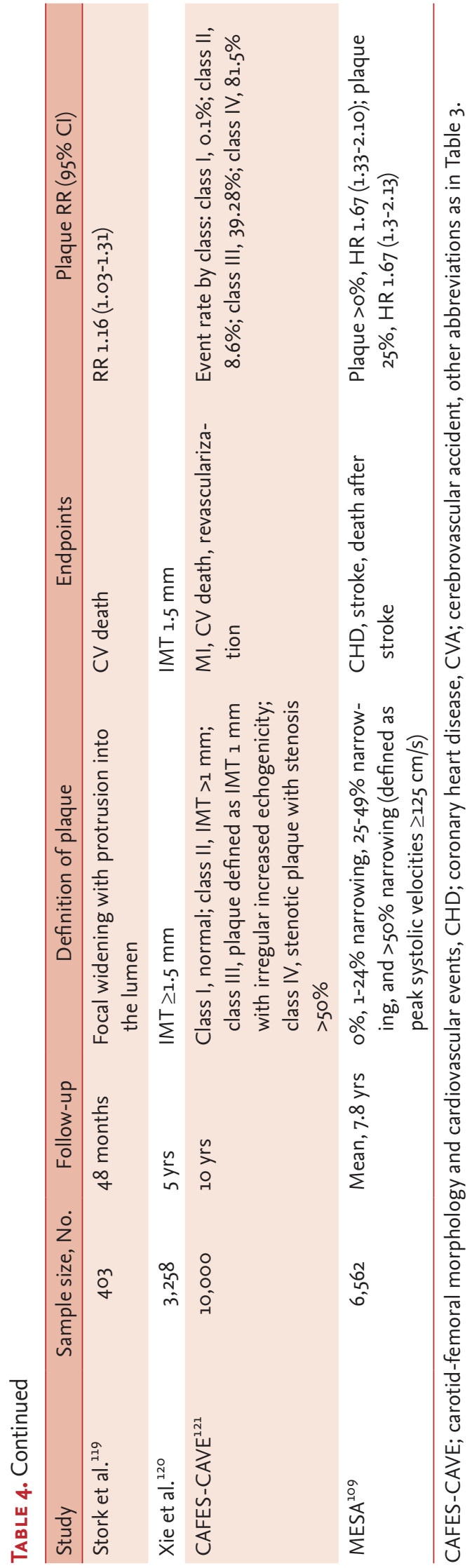

후유증을 남길 수 있는 무서운 합병증이다. 뇌졸중의 위험요소 중 하나인 경동맥협착을 발견하기 위하여 수술 전 검사로 경 동맥초음파검사가 도움이 될 수 있다. 또한, 경동맥 초음파는 협착 여부뿐만 아니라, 뇌졸중 발생과 연관이 있는 죽상경화 판 신생혈관형성, 복합죽상판(complex plaque), 죽상판궤양, 무에코음영죽상판(plaque echolucency) 및 죽상판내움직임 (intraplaque motion) 등 죽상경화판의 성질을 파악할 수 있 는 장점이 있다. ${ }^{56}$

관상동맥우회로조성술(coronary artery bypass surgery) 예정인 환자를 대상으로 비선택적으로 시행한 경동맥 초음 파에서 $50 \%$ 이상 협착은 $9 \%$ 에서, $80 \%$ 이상은 $7 \%$ 환자에 서 발견되어 일상적으로 검사를 시행하는 것은 비용 효율적이 지 못하다. ${ }^{57}$ 여러 연구에서 고령, 여성, 경동맥잡음(carotid bruit), 흡연, 당뇨, 좌주간부관상동맥질환(left main coronary artery disease), 뇌졸중의 과거력, 말초혈관질환 등이 의미 있는 경동맥 협착의 위험요소로 확인되었으며, 이 중 고 령, 뇌졸중 과거력과 말초혈관질환이 가장 많이 확인된 인자이 다. ${ }^{58}$ 한 연구에서는 65 세 이상, 뇌졸중 과거력이나 경동맥잡 음이 있는 경우 검사를 권유하였으며, 이 경우 민감도는 $83 \%$, 특이도는 $41 \%$ 라고 하였다. ${ }^{59}$ 또 다른 연구에서는 흡연, 당뇨, 고혈압, 뇌졸중 과거력, 말초혈관질환, 좌주간부관상동맥질 환, 경동맥질환의 과거력 중 한 가지라도 있는 경우 민감도는 $100 \%$, 특이도는 $30 \%$ 라 하였다. ${ }^{60}$ 미국 심장학회 관상동맥우 회로조성술 진료지침에는 65 세 이상, 좌주간부관상동맥협착, 말초혈관질환, 뇌혈관질환의 과거력, 고혈압, 흡연, 당뇨가 있 는 경우 검사를 권유한다. ${ }^{61}$

일반적인 수술인 경우 수술 후 뇌졸중 발생률은 $1 \%$ 미만 이며, 고위험군인 심장수술 중 관상동맥우회로조성술에서는 $1.4-3.8 \%$, 판막 수술에서는 4.8-8.8\% 정도이다. ${ }^{62}$ 관상동맥 우회로조성술 후 뇌졸중 발생 증가와 관계가 있는 인자는 고 령, 뇌졸중이나 일과성 허혈발작의 과거력, 말초혈관질환, 불 안정 협심증, 장시간에 걸친 심폐우회술(prolonged cardiopulmonary bypass), 수술 후 심방세동, 경동맥협착 등이 다. ${ }^{63}$ 예측인자 중 경동맥잡음 $(\mathrm{OR} 3.6,95 \%$ CI 2.8 to 4.6), 뇌졸중이나 일과성 허혈발작의 과거력(OR 3.6, $95 \%$ CI 2.7 to 4.9) 및 심한 경동맥협착이나 폐색(OR 4.3, $95 \%$ CI 3.2 to 5.7)이 위험도가 높았다. ${ }^{57}$ 경동맥의 유의한 협착이 없는 경 우 수술 후 뇌졸중 위험은 $2 \%$ 미만이었으며, 협착 정도에 따 라 무증상 동측 50-99\% 협착은 3\%, 양측 50-99\% 협착은 $5 \%$, 경동맥폐색은 7-11\%로 수술 후 뇌졸중 위험이 증가하였 다. ${ }^{57}$ 다른 연구에서는 무증상 동측 $50 \%$ 이상 협착에서는 뇌 졸중 위험이 $2 \%$ 이하인데 반하여 증후성 동측 경동맥협착 환 자에서는 $18 \%$, 양측 협착에서는 $26 \%$ 로 증후성 협착에서 수술 후 뇌졸중 위험이 더 높았다. ${ }^{64,65}$ 그러나 수술 후 뇌졸중이 발 생한 환자 $50 \%$ 에서 의미 있는 경동맥협착은 없었으며, 영역뇌 경색(territorial infarction)의 $60 \%$ 에서 경동맥질환 외에 다 
른 인자들도 연관성을 보였다. ${ }^{57}$ 다른 연구에서도 예방적 경동 맥내막절제술이나 경동맥스텐트를 하지 않은 23,557 명의 관 상동맥우회로조성술 환자 중 뇌줄중이 발생한 476 명의 $95 \%$ 는 경동맥협착이 원인이 아니었다. ${ }^{66-68}$ 실제로 심장수술 후 발행 하는 뇌졸중의 $60 \%$ 가 색전으로 인한 것으로, 수술 중 심장이 나, 대동맥을 다루는 과정, 심장 세동, 수술 후 발생하는 응고 병증(coagulopathy) 등이 원인이 된다. ${ }^{62}$ 한 연구에서는 비심 장성 수술인 경우 경동맥협착과 수술 후 뇌졸중은 연관이 없 다고 하였다(OR 1.0 [95\% CI 0.99 to 1.02] for a 10-unit increase, $p=0.55){ }^{69}$

이러한 상황에서 수술 전 예방적 경동맥재개통(carotid revascularization)은 신중하게 생각해야 한다. 경동맥 스텐트 후 관상동맥우회로조성술을 메타분석한 연구에서는 전체 30 일 사망/뇌졸중 위험은 $7.9 \%$, 사망/뇌졸중/심근경색은 $8.8 \%$ 였 으며, 무증상성 협착을 가진 환자에서는 사망/뇌졸중 위험 $6.7 \%$, 사망/뇌졸중/심근경색은 $8.5 \%$ 였다. 증후성 경동맥협착 환자에서는 시술 관련 뇌졸중 발생률은 $15 \%$, 사망/뇌졸중은 10-23\%였다. 그 외 경동맥내막절제술이나 경동맥스텐트삽입 술을 수술 전후 또는 동시에 한 여러 연구에서 경동맥내막절제 술과 심폐우회(cardiopulmonary bypass)하지 않는 관상동맥 우회로조성술을 동시에 한 경우를 제외 $(2.2,3.6 \%)$ 하고 30 일 사망/뇌졸중은 5.6-8.6\%, 사망/뇌졸중/심근경색은 5-11.5\% 정도였다. ${ }^{70}$ 유럽의 진료지침에서는 관상동맥우회로조성술에 앞서 6 개월 이내 뇌졸중이나 일과성 허혈발작이 있었던 $50-$ $99 \%$ 경동맥협착 환자나, 무증상성 양측 70-99\% 경동맥협착 또는 70-99\% 협착과 반대측 폐색이 있는 경우에 예방적 경동 맥재개통술을 권장하고 있다. ${ }^{1}$

\section{기타 질환에서 경동맥이중초음파}

\section{1. 혈관박리}

경부동맥박리(cervical artery dissection)는 모든 연령대에 서 발생할 수 있으나, 특히 젊은 연령에서 뇌혈관질환의 중요 한 원인이다. ${ }^{71}$ 혈관내막 손상으로 혈관이 좁아지면서 다양한 혈관내외의 변화를 동반한다. 가벼운 외상에 의해 내막의 손상 이 시작될 수 있고, 외상 없이 자발적으로 발생할 수도 있다. $20 \%$ 에서는 섬유근형성이상(fibromuscular dysplasia)을 동 반한다. ${ }^{71}$ 내막파열(intimal tear)이 발생하고, 시간이 지나면 서 내막(intima)과 중막(media) 사이로 벽속혈종(intramural hematoma)이 만들어진다. 혈관벽내의 출혈이 증가하면 다양 한 정도의 협착와 폐색을 유발한다. ${ }^{71,72}$ 시간이 경과하면서 벽 속혈종이 흡수되고, 막히거나 좁아진 혈관이 재개통(recanalization)된다.

바깥막하출혈(subadventitial hemorrhage)은 혈관조영 술에서 거짓꽈리(pseudoaneurysm)로 나타나고, 원위부 의 내막 손상이 발생하면 이중내강(double lumen)으로 보인 다. ${ }^{71,72}$ 박리된 혈관은 초음파영상에서 혈관벽이 저에코음영 (hypo-echogenic)으로 두껍게 관찰된다(hypo-echogenic thickening of the vessel wall).

이전에는 침습적인 혈관조영술을 이용하여 진단하였으나 영 상기술이 발전하면서 자기공명영상과 컴퓨터단층촬영을 이용 한 혈관검사로도 진단이 가능하다. 전형적인 혈관조영술 소견 은 혈관을 따라 길게 진행하는 협착이나 폐색(tapered stenosis/occlusion)이다. 특히 거짓꽈리, 이중내강 혹은 내막판

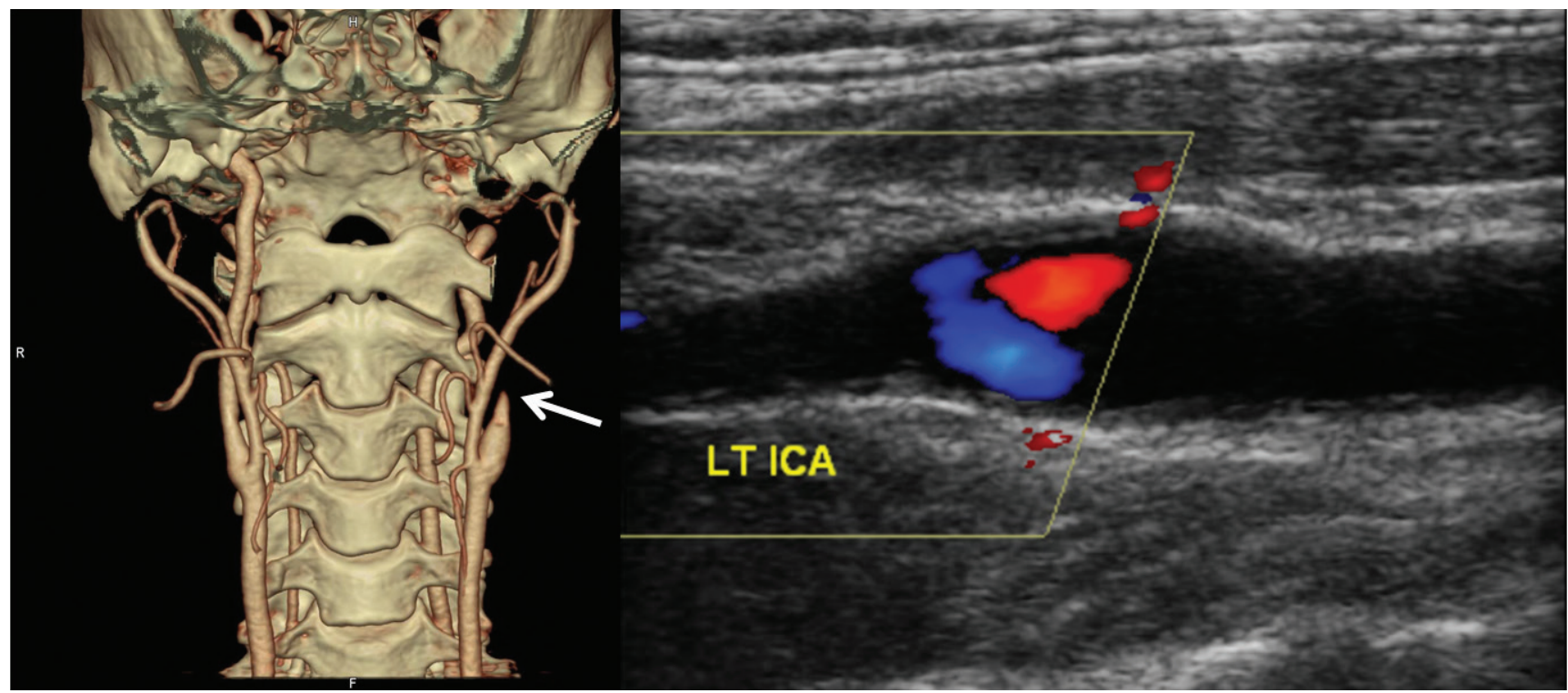

FIG. 1. Computed tomography angiography (left) and duplex sonography (right) of a patient with the left internal carotid artery dissection show tapered occlusion (arrow), and hypo-echogenic occlusion and stump flow without plaque. 
(intimal flap)이 보이면 확진 가능하다. ${ }^{71}$

1) 내경동맥박리

뇌경색을 동반하는 박리의 경동맥 초음파 민감도는 91$100 \%$ 이다. ${ }^{73,74}$ 반면, 뇌경색을 동반하지 않는 박리의 초음파 민감도는 $70 \%$ 이다. ${ }^{74}$ 뇌경색을 동반하지 않는 통증과 호너증 후군에서 박리가 의심된다면, 경동맥 초음파가 정상이라도 박 리를 배제하기 위하여 추가적인 경부 자기공명혈관촬영술이나 CT혈관조영술이 필요하다. ${ }^{75}$

내경동맥박리는 경도의 불완전협착(subtotal stenosis)부터 완전폐색까지 다양한 정도의 협착을 동반한다. 초음파에서는 죽상경화판이 거의 없는 저에코혈관벽이 원위부로 길게 가늘 어지며 진행하는 협착/폐색(tapered stenosis/occlusion)이 관찰된다(Fig. 1). 박리의 초음파 소견은 대부분 비특이적인 협착이나 폐색으로, 특징적인 내막박리판, 이중내강 혹은 거짓 꽈리가 관찰되는 경우는 오히려 드물다. ${ }^{76}$

초음파는 비침습적으로 혈관내 재개통을 확인하고 항혈전제 (antithrombotics)의 치료 기간을 결정할 수 있는 장점이 있 다. 초음파를 이용한 추적검사에서 48 명의 50예의 혈관박리 를 추적하였는데, 34예(68\%)에서 51일째에 재개통이 관찰되 었다. ${ }^{77}$ 다른 연구에서는 43 명의 환자를 추적하였을 때 $63 \%$ 가 재개통되었으나 $37 \%$ 에서는 폐색이 지속되었다. ${ }^{73}$

\section{2) 척추동맥박리}

척추동맥박리의 초음파의 민감도는 $75-86 \%$ 이다. ${ }^{72,78}$ 초 음파에서 불규칙한 협착, 낮은(hypo-) 혹은 같은 에코음 영(iso-echogenic)의 두꺼워진 혈관벽, 박리판(dissection flap), 이중내강, 거짓꽈리와 원위부로 점차적으로 가늘어지는 폐색이 보인다. 전형적인 소견으로 척추동맥에서 국소혈관의 확장, 협착 혹은 폐색 등이 동반되거나 혈관내저박동과 혈관내 에코의 존재(decreased pulsatility and presence of intra-

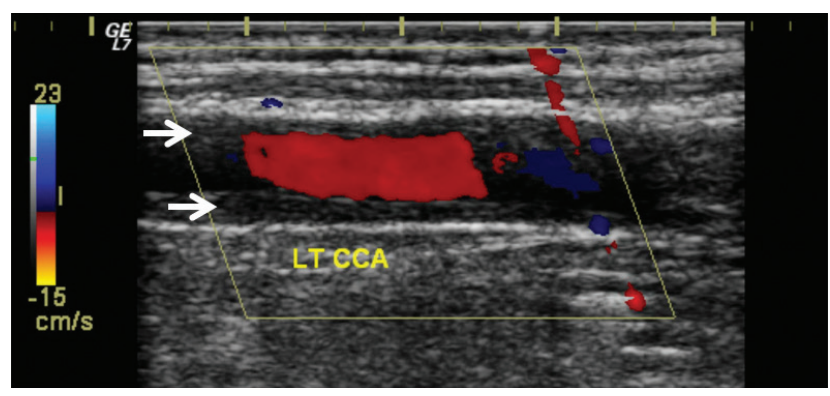

FIG. 2. Carotid duplex ultrasonography in a patient with Takayasu's arteritis. The longitudinal duplex B-mode image shows long segmental, circumferential and mid-echogenic thickenings of intimal and medial layers (Macaroni sign, arrows). vascular echoes)이다. ${ }^{72,79}$

한 추적 연구에서, 두개외 척추기저동맥박리의 경우 $80 \%$ (8/10)에서 협착이 호전되었고 29\% (2/7)에서 폐색이 재개통 되었다. ${ }^{72}$ 다른 연구에서는 두개외 척추기저동맥박리 7 명 중 협착은 50\% (3/6), 폐색은 33\% (1/3)에서 호전되었고, 두개내 척추기저동맥 혈관박리 9 명 중 협착의 $60 \%$ (6/10)와 폐색의 $33 \%(1 / 3)$ 가 좋아졌다. 78

2. 측두동맥염(temporal arteritis)과 다카야수동맥염 (Takayasu's arteritis)

측두동맥염은 50대 이상의 여자에서 주로 발생한다. 임상적 으로 측두 염증부위의 압통(tenderness), 전신무력감과 통증, 경미한 열, 턱관절의 파행과 증가된 적혈구침강속도(erythrocyte sedimentation rate)가 관찰되면 의심할 수 있다. 치 료가 늦으면 안동맥(ophthalmic artery)을 침범하여 실명까 지 이어질 수 있다. $\mathrm{B}$ 방식에서 균일하고 두터워진 저에코음영 의 혈관벽이 보인다. 급성기에는 팽창되고 두꺼워진 염증성 혈 관의 가로영상(transverse image)에서 저에코음영의 달부리 (halo)가 보인다. ${ }^{80}$ 초음파의 이상 소견은 스테로이드 치료에 의하여 서서히 호전된다. ${ }^{81}$

다카야수동맥염은 대동맥과 연결된 주요 동맥을 우선적으로 침범하는 육아종염증(granulomatous inflammation)으로 젊 은 아시아 여성에서 호발한다. 대부분 총경동맥(common carotid artery)을 침범한다. ${ }^{82,83}$ 초기에는 발열, 체중감소, 피로 감, 어지럼증, 관절통, 실신 등 비특이적인 증상이 나타날 수 있어 진단이 어렵다. 진단검사로 침습적인 혈관조영술, 자기공 명혈관촬영술이나 CT혈관조영술이 필요하다. 하지만 질병이 발생하는 초기의 혈관벽의 조직학적 변화를 확인할 수 없어서 위음성을 보일 수 있다. ${ }^{82}$ 그러나 경동맥 초음파에서 혈관벽에

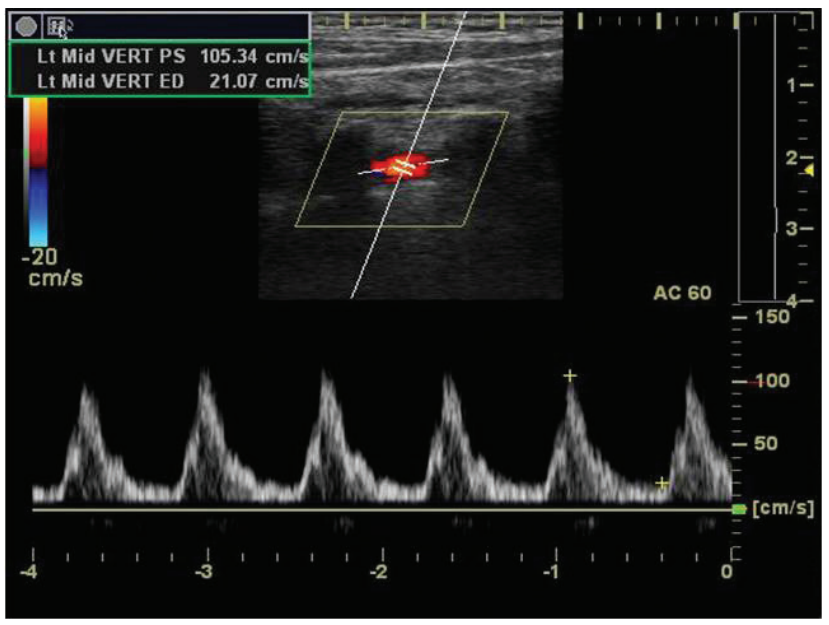

FIG. 3. Duplex sonography of a left subclavian steal phenomenon shows the reversed flow of blood in the left vertebral artery. 
고르게 퍼진 비후(Macaroni sign, homogenous circumferential intima-media thickening) 소견(Fig. 2)을 관찰할 수 있어서 혈관염을 초기에 진단할 수 있다. ${ }^{82}$ 다카야수혈관염은 측두동맥염 혈관벽의 저에코음영(hypo-echogenic)보다 밝 은 에코음영(iso-echogenic)으로 보이고, 혈관벽의 부종이 적 다. 81

\section{3. 쇄골하혈류전환증후군(subclavian steal syndrome)}

쇄골하혈류전환은 쇄골하동맥의 척추동맥 기시부 이전의 협착 혹은 폐색에 의하여 혈류의 압력이 낮아져(Bernoulli's principle), 척추동맥의 혈류가 역류하여 쇄골하동맥으로 흐르 는 현상을 일컫는다. ${ }^{84}$ 주된 원인은 죽상경화증이고 대부분은 무증상으로 발견되나 임상적으로 팔 운동에 의하여 유발되는 척추기저동맥혈류부전(vertebro-basilar insufficiency)이 동 반된다. ${ }^{84,85}$

초음파의 도플러효과를 이용하여 척추동맥의 혈류역류현상 을 확인하면 쉽게 진단할 수 있다(Fig. 3). 완전한 혈류역전의 단계가 아니라면 교대혈류(alternating flow pattern)나 수 축기 중간의 급격한 감속(prominent mid-systolic deceleration)이 전단계(pre-steal)로 관찰되어 ${ }^{85}$ 혈압계커프를 이 용한 충혈검사(hyperemia test)로 혈류역전을 유발하여 잠복 쇄골하혈류전환(latent steal phenomenon)을 진단할 수 있 다. 85

\section{어지럼증, 현훈, 이명 또는 실신 환자의 선별검사로 서의 경동맥이중초음파}

환자가 어지럼증/현훈, 이명, 혹은 실신으로 신경과로 의뢰 되거나 내원하였을 때 경동맥 초음파의 진단적 유용성은 명확 하지 않다. 이러한 증상으로 내원하여 경동맥 초음파를 시행한 650 명의 환자들을 분석한 연구에서 $60 \%$ 이상의 경동맥 협착 을 가진 환자는 없었다. ${ }^{86}$ 이러한 환자들의 수술 전 평가에서 뇌졸중이나 사망에 대한 위험성을 증가시킨다는 근거는 없고, 경동맥내막절제술 시행에 대한 장기적 이익 또한 없다. ${ }^{87}$ 실 신에 대한 진단검사에서 신경초음파의 진단적 가치는 높지 않 다. ${ }^{88}$ 어지럼증이나 현훈의 원인이 될 수 있는 척추-기저동맥 질환의 평가에 경동맥 초음파의 가치는 높지 않다. ${ }^{89}$

신경학적 이상이 없는 '단순' 실신으로 대학병원에 내원하여 경동맥 초음파를 시행받은 313 명(평균 나이 $73.6 \pm 12.4$ 세)의 의무기록을 분석한 최근의 연구에서 $50 \%$ 이상의 경동맥협착 을 보인 경우는 48 명(15\%)이었고 이는 실신과 무관하였다. ${ }^{90}$ 전체 환자 중 7 명 $(2 \%)$ 만이 향후 뇌졸중에 대비하는 약물치료 를 받았고, 1 명 $(0.3 \%)$ 만이 경동맥스텐트삽입술을 받았다. ${ }^{90}$ 즉, 실신으로 내원한 환자가 뇌졸중 발생위험이 높은 고령에
해당하더라도 국소 신경학증상, 증후를 보이지 않거나 경동맥 잡음이 없다면 경동맥 초음파의 비용대비 진단적 가치는 낮기 때문에 기본 검사로 권장되지 않는다. ${ }^{90,91}$

\section{약물치료에 있어서 경동맥이중초음파의 유용성}

죽상경화증의 치료에 있어서 적절한 약물치료는 매우 중요 하다. 특히, 경동맥협착 환자에 있어 스타틴을 사용한 약물치 료는 필수적인 요소라 할 수 있다.

경동맥 초음파를 이용하여 스타틴 치료효과를 평가한 연구 들이 있다. METEOR 연구는 관상동맥질환의 위험도가 낮은 (Framingham risk score <10\%) 무증상 죽상경화증 환자 를 대상으로 $\mathrm{B}$ 방식 초음파로 경동맥 내중막두께를 측정하여 rosuvastatin의 효과를 평가하였다. ${ }^{55} 984$ 명의 환자를 대상으 로 rosuvastatin $40 \mathrm{mg}$ 또는 위약을 복용하게 하여 약 2 년간 관찰하였다. 일차종결목표로 최대 내중막두께의 변화속도를 살펴보았는데, 위약군에서는 $+0.0131 \mathrm{~mm} / \mathrm{yr}$ 로 진행을 하였 고 투약군에서는 $\mathrm{LDL}-\mathrm{C}$ 이 약 $49 \%$ 감소하면서 내중막두께는 $-0.0014 \mathrm{~mm} / \mathrm{yr}$ 로 호전을 보였다 $(p<0.0001)$. ENHANCE 연구는 simvastatin $80 \mathrm{mg}+$ ezetimibe $10 \mathrm{mg}$ 의 병합요법 과 simvastatin $80 \mathrm{mg}$ 의 단독요법이 내중막두께에 미치는 영 향을 비교한 것이다. ${ }^{92}$ 조기 관상동맥질환의 위험이 높고 유년 기부터 내중막두께 증가속도가 높은 720 명의 가족성 고콜레스 테롤혈증 환자를 대상으로 2년간 일차종결목표인 내중막두께 를 서로 비교하였다. 연구 종결시점에 측정한 평균 $\mathrm{LDL}-\mathrm{C}$ 은 simvastatin 그룹에서 $192.7 \pm 60.3 \mathrm{mg} / \mathrm{dL}$ 였고 병합요법 그 룹에서는 $141.3 \pm 52.6 \mathrm{mg} / \mathrm{dL}$ 였다 $(p<0.01)$. 이러한 LDL-C 의 차이에도 불구하고 내중막두께의 변화는 유의한 차이가 없 었다( $p=0.29)$.

경동맥 죽상판이 있는 사람들을 대상으로 스타틴으로 치료 한 결과 초음파의 에코발생도(ecogenicity)가 어떻게 변화되 는지를 본 최근 메타분석이 있다. ${ }^{93}$ 이 분석에서는 경동맥 죽 상판의 에코성을 보는 지표로 GSM 또는 integrated back scatter (IBS)값을 사용하였다. 스타틴 치료 후 평균 7개월이 지난 시점에서 경동맥 죽상판의 에코성은 일정하게 증가하였 는데, 이는 high-sensitivity C-reactive protein (hs-CRP) 의 변화와 밀접한 연관이 있었으며 $\mathrm{LDL}-\mathrm{C}$ 이나 $\mathrm{HDL}-\mathrm{C}$ 의 변 화와는 연관이 없었다. 이는 스타틴 치료가 불안정한 죽상판을 보다 더 안정화된 죽상판으로 변화시킬 수 있음을 보여주는 것 이라 할 수 있다. 스타틴 사용은 $\mathrm{LDL}-\mathrm{C}$ 감소 효과뿐 아니라 경동맥죽상경화증의 진행을 늦춘다는 결과도 있다. ${ }^{94} 2,974$ 명 의 건강인을 대상으로 한 Tromsø 연구는 경동맥 초음파로 13 년간 내중막두께와 죽상판을 추적 관찰하였는데, 종류와 용 량에 관계없는 스타틴 치료는 경동맥죽상경화의 진행을 늦추 었다. 특히, 5 년 이상의 장기간 스타틴 투여군에서 내중막두께 
$(\beta=-0.0387 \mathrm{~mm} ; p=0.002)$ 와 전체 죽상판 면적 $\left(\beta=-0.400 \mathrm{~mm}^{2}\right.$; $p=0.006$ )에서 진행을 억제하는 보호 효과가 있었다. 건강인 이 아닌 뇌졸중을 경험한 경동맥 협착 환자에서도 스타틴 치료 는 죽상판 안정화에 효과를 주었다. 한 연구에서 경동맥 초음 파에서 죽상판 영상을 얻은 후 이미지 소프트웨어를 사용하여 $\mathrm{GSM}$ 값을 구하여 atorvastatin $40 \mathrm{mg}$ 과 $80 \mathrm{mg}$ 치료 전과 치료 1년 후를 비교하였다. 최종적으로 atorvastatin 저용량 과 고용량은 위약군에 비하여 용량 의존적으로 죽상판을 안정 화 시켰으며 고용량에서 가장 큰 효과를 보였다. ${ }^{95}$

\section{경부혈관 초음파의 임상적 적용 - 표준검사지침 요약 $32,39,96-98$}

지금까지의 논거한 결과들을 바탕으로 임상에서 시행할 경 동맥초음파의 표준검사지침을 요약적으로 제시하고자 한다.

- 경동맥 초음파는 양측 경동맥과 척추동맥을 모두 검사하 는 것을 원칙으로 하고 $\mathrm{B}$ 방식과 도플러속도검사가 포함 되어야 한다.

- 경동맥 초음파의 필요 여부는 대상자의 임상증상, 병력, 다른 검사 결과 등을 토대로 결정한다. 일반적으로 관련 증상, 병력이 없는 사람에서 선별검사의 목적으로 경동맥 초음파를 시행하는 것은 권고하지 않는다. ${ }^{39,99}$

다음과 같은 경우에 경동맥 초음파를 시행하거나, 고려할 수 있다.

1. 초기 검사

1) 경동맥이나 척추동맥의 병변이 의심되는 경우

ㅁ 전방순환계의 이상으로 인한 것으로 추정되는 신경학적 증상이 새로 생겼거나, 기존 증상이 악화된 경우

ㅁ 후방순환계의 이상으로 인한 것으로 추정되는 신경학적 증상이 새로 생겼거나, 기존 증상이 악화된 경우

ㅁ 팔 운동을 과하게 하였을 때 발생하는 어지럼증, 두통, 시야장애 등의 증상으로 쇄골하혈류전환증후군이 의심되 는 경우

ㅁ 목에 박동성 병변이 있는 환자에서 자발성경동맥박리에 대한 평가

ㅁ 망막검사에서 Hollenhorst plaque이 관찰되는 경우

ㅁ 경동맥잡음이 들리고 이전에 경동맥검사를 시행한 적이 없는 경우

2) 이미 경동맥이나 척추동맥 이상이 진단되었으나, 혈관재 개통술은 시행받지 않은 경우
3) 관상동맥우회로조성술 시행 예정인 65 세 이상의 환자와 좌주간부관상동맥협착, 말초동맥협착, 흡연, 뇌졸중이나 일과성 허혈발작의 병력, 또는 경동맥잡음 환자에서 선 별검사를 고려할 수 있다. ${ }^{58-61,70}$

4) 죽상경화증의 근거가 없는 무증상 환자에서 고혈압, 고 지혈증, 흡연, 60 세 미만 직계가족의 죽상경화증, 또는 뇌경색 가족력 2 개 이상의 위험요인을 가진 경우에 선별 검사를 고려할 수 있다. ${ }^{32}$

5) 심혈관질환 위험을 평가하기 위하여 다음과 같은 환자 에서 경동맥 초음파검사를 고려할 수 있다. (1) 중등도 의 심혈관질환 위험을 가진 사람, (2) 직계가족 중 조기 심혈관질환이 있는 사람, (3) 하나의 확실한 위험인자가 있는 60 세 미만 환자, (4) 두개 이상의 위험인자를 가진 60세 미만 여자.

2. 추적검사

1) 이미 경동맥 이상이 진단되었으나, 혈관재개통술은 시행 받지 않은 경우

ㅁ 70-99\%의 경동맥 협착 환자에서는 6 개월마다 추적검사 를 시행하는 것이 적절하다

ㅁ 50-69\%의 경동맥 협착 환자에서 1 년마다 추적검사를 시 행하는 것이 적절하다.

2) 이미 경동맥이나 척추동맥 이상이 진단되고, 혈관재개통 술을 시행받은 경우

ㅁ 새로운 신경학적 증상이 발생하거나 기존 증상이 악화되 는 경우

ㅁ 경동맥스텐트삽입술 이후 퇴원 전, 3 개월 후, 이후로는 6 개 월 간격으로 3 회 경동맥 초음파를 시행하도록 하며, 2 년 동안 스텐트내재협착이 없을 경우에는 이후 1년마다 평 가하기를 권장한다. ${ }^{27}$

ㅁ 경동맥내막절제술에서 일차봉합을 한 경우 추적검사는 1 개 월, 6 개월, 이후 1 년마다 시행할 것을 권고하고, ${ }^{32}$ 부분혈 관성형의 경우 6 개월째 추적검사에서 정상일 때에는 정 기적인 추적검사가 권장되지 않는다. ${ }^{33}$

ㅁ 추적검사에서 이상을 보이는 경우에는 혈관재개통술을 다시 시행할지 여부에 대하여 6 개월마다 추적검사를 해 서 결정하는 것이 적절하다.

ㅁ 더 이상 시술의 대상이 아니라고 판단되면 추적검사를 종 료할 수 있다. 
3) 이전에 시행한 경동맥 초음파에서 정상이었던 경우에 추 적검사를 시행하는 것은 적절하지 않다.

4) 죽상경화판은 있으나 협착이 없는 경우 1 년 이내에 추적 검사를 시행하는 것은 적절하지 않다.

5) $50 \%$ 미만의 경동맥협착의 경우 추적검사를 1-2년 이상 의 간격으로 시행하는 것에 대한 근거는 불충분하다.

6) 두개외 경동맥 섬유근육형성이상 환자에서 매년 추적검 사를 시행하는 것은 타당하나, 예후에 대한 효과는 불분 명하다. 혈관병변이 안정적인 소견일 경우, 추적검사 간 격을 조정할 수 있다.

\section{Sources of Funding \\ None}

\section{Conflicts of Interest}

None

\section{REFERENCES}

1. Naylor AR, Ricco JB, de Borst GJ, Debus S, de Haro J, Halliday A, et al. Editor's choice - management of atherosclerotic carotid and vertebral artery disease: 2017 clinical practice guidelines of the European Society for Vascular Surgery (ESVS). Eur J Vasc Endovasc Surg. 2018;55:3-81.

2. Lee JY, Yu S, Lee SI, Jung KH, Seo WK, Park JM, et al. Transcranial Doppler ultrasound: practice standards part I. Test performance and interpiretation. J Neursonology. 2016;8:1-13.

3. Jung KH, Seo WK, Park JM, Lee JY, Yu S, Lee SI, et al. Transcranial Doppler ultrasound: practice standards part II. Clinical indications and utility. J Neursonology. 2016;8:14-29.

4. Naylor AR. Why is the management of asymptomatic carotid disease so controversial? Surgeon. 2015;13:34-43.

5. White H, Boden-Albala B, Wang C, Elkind MS, Rundek T, Wright $\mathrm{CB}$, et al. Ischemic stroke subtype incidence among whites, blacks, and hispanics: the Northern Manhattan study. Circulation. 2005;111:1327-1331.

6. Brott TG, Halperin JL, Abbara S, Bacharach JM, Barr JD, Bush RL, et al. 2011 ASA/ACCF/AHA/AANN/AANS/ACR/ ASNR/CNS/SAIP/SCAI/SIR/SNIS/SVM/SVS guideline on the management of patients with extracranial carotid and vertebral artery disease: executive summary: a report of the American College of Cardiology Foundation/American Heart Association task force on practice guidelines, and the American Stroke Association, American Association of Neuroscience Nurses, American Association of Neurological Surgeons, American College of Radiology, American Society of Neuroradiology, Congress of Neurological Surgeons, Society of Atherosclerosis Imaging and Prevention, Society for Cardiovascular Angiography and Interventions, Society of Interventional Radiology, Society of NeuroInterventional Surgery, Society for Vascular Medicine, and Society for Vascular Surgery. Developed in collaboration with the American Academy of Neurology and Society of Cardiovascular Computed Tomography. Catheter Cardiovasc Interv. 2013;81:E76-E123.

7. Randomised trial of endarterectomy for recently symptomatic carotid stenosis: final results of the MRC European Carotid Surgery trial (ECST). Lancet. 1998;351:1379-1387.

8. North American Symptomatic Carotid Endarterectomy Trial Collaborators, Barnett HJM, Taylor DW, Haynes RB, Sackett DL, Peerless SJ, et al. Beneficial effect of carotid endarterectomy in symptomatic patients with high-grade carotid stenosis. N Engl J Med. 1991;325:445-453.

9. Bonati LH, Dobson J, Featherstone RL, Ederle J, van der Worp HB, de Borst GJ, et al. Long-term outcomes after stenting versus endarterectomy for treatment of symptomatic carotid stenosis: the International Carotid Stenting Study (ICSS) randomised trial. Lancet. 2015;385:529-538.

10. Carpenter JP, Lexa FJ, Davis JT. Determination of duplex Doppler ultrasound criteria appropriate to the North American Symptomatic Carotid Endarterectomy Trial. Stroke. 1996;27:695-699.

11. Grant EG, Benson CB, Moneta GL, Alexandrov AV, Baker JD, Bluth EI, et al. Carotid artery stenosis: gray-scale and Doppler us diagnosis--Society of Radiologists in Ultrasound Consensus Conference. Radiology. 2003;229:340-346.

12. Wardlaw JM, Chappell FM, Stevenson M, De Nigris E, Thomas S, Gillard J, et al. Accurate, practical and cost-effective assessment of carotid stenosis in the UK. Health Technol Assess. 2006;10:iii-iv, ix-x, 1-182.

13. AbuRahma AF, Srivastava M, Stone PA, Mousa AY, Jain A, Dean LS, et al. Critical appraisal of the Carotid Duplex Consensus criteria in the diagnosis of carotid artery stenosis. J Vasc Surg. 2011;53:53-59; discussion 59-60.

14. Byrnes KR, Ross CB. The current role of carotid duplex ultrasonography in the management of carotid atherosclerosis: foundations and advances. Int J Vasc Med. 2012;2012:187872. 
15. Pavela J, Ahanchi S, Steerman SN, Higgins JA, Panneton JM. Grayscale median analysis of primary stenosis and restenosis after carotid endarterectomy. J Vasc Surg. 2014;59:978-982.

16. Willfort-Ehringer A, Ahmadi R, Gruber D, Gschwandtner ME, Haumer A, Haumer M, et al. Arterial remodeling and hemodynamics in carotid stents: a prospective duplex ultrasound study over 2 years. J Vasc Surg. 2004;39:728-734.

17. Hirschl M, Bernt RA, Hirschl MM. Carotid endarterectomy (ce) of the internal carotid artery (ica) with and without patch angioplasty: comparison of hemodynamical and morphological parameters. Int Angiol. 1989;8:10-15.

18. Nederkoorn PJ, Brown MM. Optimal cut-off criteria for duplex ultrasound for the diagnosis of restenosis in stented carotid arteries: review and protocol for a diagnostic study. BMC Neurol. 2009;9:36.

19. Lal BK, Hobson RW 2nd, Goldstein J, Chakhtoura EY, Durán WN. Carotid artery stenting: Is there a need to revise ultrasound velocity criteria? J Vasc Surg. 2004;39:58-66.

20. AbuRahma AF, Abu-Halimah S, Bensenhaver J, Dean LS, Keiffer T, Emmett M, et al. Optimal carotid duplex velocity criteria for defining the severity of carotid in-stent restenosis. J Vasc Surg. 2008;48:589-594.

21. Peterson BG, Longo GM, Kibbe MR, Matsumura JS, Blackburn D, Astleford P, et al. Duplex ultrasound remains a reliable test even after carotid stenting. Ann Vasc Surg. 2005;19: 793-797

22. Kallmayer M, Tsantilas P, Zieger C, Ahmed A, Sollner H, Zimmermann A, et al. Ultrasound surveillance after cas and cea: what's the evidence? J Cardiovasc Surg (Torino). 2014;55:3341.

23. Lal BK, Hobson RW 2nd, Goldstein J, Geohagan M, Chakhtoura E, Pappas PJ, et al. In-stent recurrent stenosis after carotid artery stenting: life table analysis and clinical relevance. J Vasc Surg. 2003;38:1162-1168; discussion 1169.

24. Stanziale SF, Wholey MH, Boules TN, Selzer F, Makaroun MS. Determining in-stent stenosis of carotid arteries by duplex ultrasound criteria. J Endovasc Ther. 2005;12:346-353.

25. Chahwan S, Miller MT, Pigott JP, Whalen RC, Jones L, Comerota AJ. Carotid artery velocity characteristics after carotid artery angioplasty and stenting. J Vasc Surg. 2007;45:523-526.

26. Lal BK, Hobson RW 2nd, Tofighi B, Kapadia I, Cuadra S, Jamil Z. Duplex ultrasound velocity criteria for the stented carotid artery. J Vasc Surg. 2008;47:63-73.

27. Cao P DP. Rutherford's vascular surgery. Philadelphia: Saunders Elsevier, 2010.
28. Sadideen H, Taylor PR, Padayachee TS. Restenosis after carotid endarterectomy. Int J Clin Pract. 2006;60:1625-1630.

29. Bernstein EF, Torem S, Dilley RB. Does carotid restenosis predict an increased risk of late symptoms, stroke, or death? Ann Surg. 1990;212:629-636.

30. Mattos MA, Shamma AR, Rossi N, Meng R, Godersky J, Loftus C, et al. Is duplex follow-up cost-effective in the first year after carotid endarterectomy? Am J Surg. 1988;156:91-95.

31. Bond R, Rerkasem K, Naylor AR, Aburahma AF, Rothwell PM. Systematic review of randomized controlled trials of patch angioplasty versus primary closure and different types of patch materials during carotid endarterectomy. $J$ Vasc Surg. 2004;40:1126-1135.

32. Brott TG, Halperin JL, Abbara S, Bacharach JM, Barr JD, Bush RL, et al. 2011 ASA/ACCF/AHA/AANN/AANS/ACR/ ASNR/CNS/SAIP/SCAI/SIR/SNIS/SVM/SVS guideline on the management of patients with extracranial carotid and vertebral artery disease: executive summary: a report of the American College of Cardiology Foundation/American Heart Association task force on practice guidelines, and the American Stroke Association, American Association of Neuroscience Nurses, American Association of Neurological Surgeons, American College of Radiology, American Society of Neuroradiology, Congress of Neurological Surgeons, Society of Atherosclerosis Imaging and Prevention, Society for Cardiovascular Angiography and Interventions, Society of Interventional Radiology, Society of NeuroInterventional Surgery, Society for Vascular Medicine, and Society for Vascular Surgery. Vasc Med. 2011;16:35-77.

33. Aburahma AF. Duplex criteria for determining $\geq 50 \%$ and $\geq 80 \%$ internal carotid artery stenosis following carotid endarterectomy with patch angioplasty. Vascular. 2011;19:15-20.

34. Wasser K, Schnaudigel S, Wohlfahrt J, Psychogios MN, Schramm P, Knauth M, et al. Clinical impact and predictors of carotid artery in-stent restenosis. J Neurol. 2012;259:18961902.

35. Rundek T, Polak JF. Cardiovascular risk factors and carotid ultrasound. In: Alexandrov AV. Cerebrovascular ultrasound in stroke prevention and treatment. 2nd ed. New York: Wiley-Blackwell, 2011;158-176.

36. Nicolaides AN, Kakkos SK, Griffin M, Sabetai M, Dhanjil $\mathrm{S}$, Tegos T, et al. Severity of asymptomatic carotid stenosis and risk of ipsilateral hemispheric ischaemic events: Results from the ACSRS study. Eur J Vasc Endovasc Surg. 2005;30:275-284.

37. Lewis RF, Abrahamowicz M, Côté R, Battista RN. Predictive 
power of duplex ultrasonography in asymptomatic carotid disease. Ann Intern Med. 1997;127:13-20.

38. Polak JF, Shemanski L, O'Leary DH, Lefkowitz D, Price TR, Savage PJ, et al. Hypoechoic plaque at us of the carotid artery: an independent risk factor for incident stroke in adults aged 65 years or older. Cardiovascular health study. Radiology. 1998;208:649-654.

39. LeFevre ML, Force USPST. Screening for asymptomatic carotid artery stenosis: U.S. Preventive Services Task Force recommendation statement. Ann Intern Med. 2014;161:356362.

40. Davies MJ, Richardson PD, Woolf N, Katz DR, Mann J. Risk of thrombosis in human atherosclerotic plaques: role of extracellular lipid, macrophage, and smooth muscle cell content. Br Heart J. 1993;69:377-381.

41. Falk E. Why do plaques rupture? Circulation. 1992;86:III3O$\mathrm{III}_{42}$.

42. Greenland P, Abrams J, Aurigemma GP, Bond MG, Clark LT, Criqui MH, et al. Prevention conference V: beyond secondary prevention: identifying the high-risk patient for primary prevention: noninvasive tests of atherosclerotic burden: Writing group III. Circulation. 2000;101:E16-E22.

43. National Cholesterol Education Program Expert Panel on Detection E, Treatment of High Blood Cholesterol in A. Third report of the National Cholesterol Education Program (NCEP) expert panel on detection, evaluation, and treatment of high blood cholesterol in adults (adult treatment panel III) final report. Circulation. 2002;106:3143-3421.

44. Greenland P, Alpert JS, Beller GA, Benjamin EJ, Budoff MJ, Fayad ZA, et al. 2010 ACCF/AHA guideline for assessment of cardiovascular risk in asymptomatic adults: a report of the American College of Cardiology Foundation/American Heart Association task force on practice guidelines. J Am Coll Cardiol. 2010;56:e50-e103.

45. Stein JH, Korcarz CE, Hurst RT, Lonn E, Kendall CB, Mohler ER, et al. Use of carotid ultrasound to identify subclinical vascular disease and evaluate cardiovascular disease risk: A consensus statement from the American Society of Echocardiography carotid intima-media thickness task force. Endorsed by the Society for Vascular Medicine. J Am Soc Echocardiogr. 2008;21:93-111; quiz 189-190.

46. O'Leary DH, Polak JF, Kronmal RA, Manolio TA, Burke GL, Wolfson SK Jr. Carotid-artery intima and media thickness as a risk factor for myocardial infarction and stroke in older adults. Cardiovascular health study collaborative research group. N Engl J Med. 1999;340:14-22.
47. Touboul PJ, Hennerici MG, Meairs S, Adams H, Amarenco P, Bornstein N, et al. Mannheim carotid intima-media thickness and plaque consensus (2004-2006-2011). An update on behalf of the advisory board of the 3rd, 4 th and 5 th watching the risk symposia, at the 13th, 15th and 2oth European Stroke Conferences, Mannheim, Germany, 2004, Brussels, Belgium, 2006, and Hamburg, Germany, 2011. Cerebrovasc Dis. 2012;34:290-296.

48. Inaba Y, Chen JA, Bergmann SR. Carotid plaque, compared with carotid intima-media thickness, more accurately predicts coronary artery disease events: a meta-analysis. Atherosclerosis. 2012;220:128-133.

49. Spence JD. Carotid plaque measurement is superior to imt invited editorial comment on: carotid plaque, compared with carotid intima-media thickness, more accurately predicts coronary artery disease events: a meta-analysis-Yoichi Inaba, M.D., Jennifer A. Chen M.D., Steven R. Bergmann M.D., Ph.D. Atherosclerosis. 2012;220:34-35.

50. Nambi V, Chambless L, Folsom AR, He M, Hu Y, Mosley $\mathrm{T}$, et al. Carotid intima-media thickness and presence or absence of plaque improves prediction of coronary heart disease risk: the ARIC (atherosclerosis risk in communities) study. J Am Coll Cardiol. 2010;55:1600-1607.

51. Plichart M, Celermajer DS, Zureik M, Helmer C, Jouven X, Ritchie K, et al. Carotid intima-media thickness in plaquefree site, carotid plaques and coronary heart disease risk prediction in older adults. The three-city study. Atherosclerosis. 2011;219:917-924.

52. Mathiesen EB, Johnsen SH, Wilsgaard T, Bønaa KH, Løchen ML, Njølstad I. Carotid plaque area and intima-media thickness in prediction of first-ever ischemic stroke: a 10-year follow-up of 6584 men and women: the TROMS $\varnothing$ study. Stroke. 2011;42:972-978.

53. Baldassarre D, Hamsten A, Veglia F, de Faire U, Humphries SE, Smit AJ, et al. Measurements of carotid intima-media thickness and of interadventitia common carotid diameter improve prediction of cardiovascular events: results of the improve (carotid intima media thickness [IMT] and IMT-progression as predictors of vascular events in a high risk European population) study. J Am Coll Cardiol. 2012;60:1489-1499.

54. Lorenz MW, Polak JF, Kavousi M, Mathiesen EB, Volzke $\mathrm{H}$, Tuomainen TP, et al. Carotid intima-media thickness progression to predict cardiovascular events in the general population (the PROG-IMT collaborative project): a meta-analysis of individual participant data. Lancet. 
2012;379:2053-2062.

55. Crouse JR 3rd, Raichlen JS, Riley WA, Evans GW, Palmer MK, O'Leary DH, et al. Effect of rosuvastatin on progression of carotid intima-media thickness in low-risk individuals with subclinical atherosclerosis: the METEOR trial. JAMA. 2007;297:1344-1353.

56. Brinjikji W, Rabinstein AA, Lanzino G, Murad MH, Williamson EE, DeMarco JK, et al. Ultrasound characteristics of symptomatic carotid plaques: a systematic review and meta-analysis. Cerebrovasc Dis. 2015;40:165-174.

57. Naylor AR, Mehta Z, Rothwell PM, Bell PR. Carotid artery disease and stroke during coronary artery bypass: a critical review of the literature. Eur J Vasc Endovasc Surg. 2002;23:283294.

58. Masabni K, Raza S, Blackstone EH, Gornik HL, Sabik JF $3 \mathrm{rd}$. Does preoperative carotid stenosis screening reduce perioperative stroke in patients undergoing coronary artery bypass grafting? J Thorac Cardiovasc Surg. 2015;149:1253-1260.

59. Durand DJ, Perler BA, Roseborough GS, Grega MA, Borowicz LM Jr, Baumgartner WA, et al. Mandatory versus selective preoperative carotid screening: a retrospective analysis. Ann Thorac Surg. 2004;78:159-166; discussion 159-166.

6o. Sheiman RG, Janne d'Othee B. Screening carotid sonography before elective coronary artery bypass graft surgery: who needs it. AJR Am J Roentgenol. 2007;188:W475-W479.

61. Hillis LD, Smith PK, Anderson JL, Bittl JA, Bridges CR, Byrne JG, et al. 2011 ACCF/AHA guideline for coronary artery bypass graft surgery. A report of the American College of Cardiology Foundation/American Heart Association task force on practice guidelines. Developed in collaboration with the American Association for Thoracic Surgery, Society of Cardiovascular Anesthesiologists, and Society of Thoracic Surgeons. J Am Coll Cardiol. 2011;58:e123-e210.

62. Selim M. Perioperative stroke. N Engl J Med. 2007;356:706713.

63. Mao Z, Zhong X, Yin J, Zhao Z, Hu X, Hackett ML. Predictors associated with stroke after coronary artery bypass grafting: a systematic review. J Neurol Sci. 2015;357:1-7.

64. Naylor AR, Bown MJ. Stroke after cardiac surgery and its association with asymptomatic carotid disease: an updated systematic review and meta-analysis. Eur J Vasc Endovasc Surg. 2011;41:607-624.

65. D'Agostino RS, Svensson LG, Neumann DJ, Balkhy HH, Williamson WA, Shahian DM. Screening carotid ultrasonography and risk factors for stroke in coronary artery surgery patients. Ann Thorac Surg. 1996;62:1714-1723.
66. Stamou SC, Hill PC, Dangas G, Pfister AJ, Boyce SW, Dullum $\mathrm{MK}$, et al. Stroke after coronary artery bypass: incidence, predictors, and clinical outcome. Stroke. 2001;32:1508-1513.

67. Li Y, Walicki D, Mathiesen C, Jenny D, Li Q, Isayev Y, et al. Strokes after cardiac surgery and relationship to carotid stenosis. Arch Neurol. 2009;66:1091-1096.

68. Schoof J, Lubahn W, Baeumer M, Kross R, Wallesch CW, Kozian A, et al. Impaired cerebral autoregulation distal to carotid stenosis/occlusion is associated with increased risk of stroke at cardiac surgery with cardiopulmonary bypass. $J$ Thorac Cardiovasc Surg. 2007;134:690-696.

69. Sonny A, Gornik HL, Yang D, Mascha EJ, Sessler DI. Lack of association between carotid artery stenosis and stroke or myocardial injury after noncardiac surgery in high-risk patients. Anesthesiology. 2014;121:922-929.

70. Paraskevas KI, Nduwayo S, Saratzis AN, Naylor AR. Carotid stenting prior to coronary bypass surgery: an updated systematic review and meta-analysis. Eur J Vasc Endovasc Surg. 2017;53:309-319.

71. Hart RG, Easton JD. Dissections. Stroke. 1985;16:925-927.

72. Bartels E, Flügel KA. Evaluation of extracranial vertebral artery dissection with duplex color-flow imaging. Stroke. 1996;27:290-295.

73. Sturzenegger M, Mattle HP, Rivoir A, Baumgartner RW. Ultrasound findings in carotid artery dissection: analysis of 43 patients. Neurology. 1995;45:691-698.

74. Baumgartner RW, Arnold M, Baumgartner I, Mosso M, Gönner F, Studer A, et al. Carotid dissection with and without ischemic events: local symptoms and cerebral artery findings. Neurology. 2001;57:827-832.

75. Arnold M, Baumgartner RW, Stapf C, Nedeltchev K, Buffon F, Benninger D, et al. Ultrasound diagnosis of spontaneous carotid dissection with isolated Horner syndrome. Stroke. 2008;39:82-86.

76. Benninger DH, Baumgartner RW. Ultrasound diagnosis of cervical artery dissection. Front Neurol Neurosci. 2006;21:7084.

77. Steinke W, Rautenberg W, Schwartz A, Hennerici M. Noninvasive monitoring of internal carotid artery dissection. Stroke. 1994;25:998-1005.

78. de Bray JM, Penisson-Besnier I, Dubas F, Emile J. Extracranial and intracranial vertebrobasilar dissections: diagnosis and prognosis. J Neurol Neurosurg Psychiatry. 1997;63:46-51.

79. Touboul PJ, Mas JL, Bousser MG, Laplane D. Duplex scanning in extracranial vertebral artery dissection. Stroke. 1988;19:116-121. 
8o. Karassa FB, Matsagas MI, Schmidt WA, Ioannidis JA. Meta-analysis: test performance of ultrasonography for giant-cell arteritis. Ann Int Med. 2005;142:359-369.

81. Schmidt WA. Takayasu and temporal arteritis. Front Neurol Neurosci. 2006;21:96-104.

82. Maeda H, Handa N, Matsumoto M, Hougaku H, Ogawa S, Oku N, et al. Carotid lesions detected by B-mode ultrasonography in Takayasu's arteritis: "macaroni sign" as an indicator of the disease. Ultrasound Med Biol. 1991;17:695-701.

83. Sun Y, Yip PK, Jeng JS, Hwang BS, Lin WH. Ultrasonographic study and long-term follow-up of Takayasu's arteritis. Stroke. 1996;27:2178-2182.

84. Jung KH, Kim JM, Lee ST, Chu K, Roh JK. Brain response characteristics associated with subclavian steal phenomenon. J Stroke Cerebrovasc Dis. 2014;23:e157-e161.

85. Kliewer MA, Hertzberg BS, Kim DH, Bowie JD, Courneya DL, Carroll BA. Vertebral artery Doppler waveform changes indicating subclavian steal physiology. AJR Am J Roentgenol. 2000;174:815-819.

86. Rodriguez G, Delmonte M, Vitali P, Bordoni C, Barone C, Nobili F. Duplex scanning of neck vessels: need for extending the consensus on indications. Neurol Sci. 2002;22:437-441.

87. Qureshi AI, Janjua N, Kirmani JF, Harris-Lane P, Suri MF, Zhou J, et al. Mechanical disruption of thrombus following intravenous tissue plasminogen activator for ischemic stroke. J Neuroimaging. 2007;17:124-130.

88. Linzer M, Yang EH, Estes NA 3rd, Wang P, Vorperian VR, Kapoor WN. Diagnosing syncope. Part 1: value of history, physical examination, and electrocardiography. Clinical efficacy assessment project of the American College of Physicians. Ann Intern Med. 1997;126:989-996.

89. Savitz SI, Caplan LR. Vertebrobasilar disease. N Engl J Med. 2005;352:2618-2626

90. Scott JW, Schwartz AL, Gates JD, Gerhard-Herman M, Havens JM. Choosing wisely for syncope: low-value carotid ultrasound use. J Am Heart Assoc. 2014;3:e001063.

91. Schnipper JL, Ackerman RH, Krier JB, Honour M. Diagnostic yield and utility of neurovascular ultrasonography in the evaluation of patients with syncope. Mayo Clin Proc. 2005;80:480-488.

92. Kastelein JJ, Akdim F, Stroes ES, Zwinderman AH, Bots ML, Stalenhoef AF, et al. Simvastatin with or without ezetimibe in familial hypercholesterolemia. $N$ Engl J Med. 2008;358:1431-1443.

93. Ibrahimi P, Jashari F, Bajraktari G, Wester P, Henein MY. Ultrasound assessment of carotid plaque echogenicity response to statin therapy: a systematic review and meta-analysis. Int J Mol Sci. 2015;16:10734-10747.

94. Herder M, Arntzen KA, Johnsen SH, Eggen AE, Mathiesen EB. Long-term use of lipid-lowering drugs slows progression of carotid atherosclerosis: the TROMSØ study 1994 to 2008. Arterioscler Thromb Vasc Biol. 2013;33:858-862.

95. Marchione P, Vento C, Morreale M, Izzo C, Maugeri A, Manuppella F, et al. Atorvastatin treatment and carotid plaque morphology in first-ever atherosclerotic transient ischemic attack/stroke: a case-control study. J Stroke Cerebrovasc Dis. 2015;24:138-143.

96. Norgren L, Hiatt WR, Dormandy JA, Nehler MR, Harris KA, Fowkes FG, et al. Inter-society consensus for the management of peripheral arterial disease (TASC II). Eur J Vasc Endovasc Surg. 2007;33 Suppl 1:S1-S75.

97. Qureshi AI, Alexandrov AV, Tegeler CH, Hobson RW 2nd, Dennis Baker J, Hopkins LN. Guidelines for screening of extracranial carotid artery disease: a statement for healthcare professionals from the multidisciplinary practice guidelines committee of the American Society of Neuroimaging; cosponsored by the Society of Vascular and Interventional Neurology. J Neuroimaging. 2007;17:19-47.

98. Mohler ER, 3rd, Gornik HL, Gerhard-Herman M, Misra $\mathrm{S}$, Olin JW, Zierler RE, et al. ACCF/ACR/AIUM/ASE/ASN/ ICAVL/SCAI/SCCT/SIR/SVM/SVS/SVU [corrected] 2012 appropriate use criteria for peripheral vascular ultrasound and physiological testing part i: arterial ultrasound and physiological testing: a report of the American College of Cardiology Foundation appropriate use criteria task force, American College of Radiology, American Institute of Ultrasound in Medicine, American Society of Echocardiography, American Society of Nephrology, Intersocietal Commission for the Accreditation of Vascular Laboratories, Society for Cardiovascular Angiography and Interventions, Society of Cardiovascular Computed Tomography, Society for Interventional Radiology, Society for Vascular Medicine, Society for Vascular Surgery, [corrected] and Society for Vascular Ultrasound. [corrected]. J Am Coll Cardiol. 2012;60:242-276.

99. Jonas DE, Feltner C, Amick HR, Sheridan S, Zheng ZJ, Watford DJ, et al. Screening for asymptomatic carotid artery stenosis: a systematic review and meta-analysis for the U.S. Preventive Services Task Force. Ann Intern Med. 2014;161:336346.

100. Salonen JT, Salonen R. Ultrasonographically assessed carotid morphology and the risk of coronary heart disease. Arterioscler Thromb. 1991;11:1245-1249. 
101. Cao JJ, Arnold AM, Manolio TA, Polak JF, Psaty BM, Hirsch $\mathrm{CH}$, et al. Association of carotid artery intima-media thickness, plaques, and C-reactive protein with future cardiovascular disease and all-cause mortality: the Cardiovascular Health Study. Circulation. 2007;116:32-38.

102. Chambless LE, Heiss G, Folsom AR, Rosamond W, Szklo M, Sharrett AR, et al. Association of coronary heart disease incidence with carotid arterial wall thickness and major risk factors: the Atherosclerosis Risk in Communities (ARIC) study, 1987-1993. Am J Epidemiol. 1997;146:483-494.

103. Lorenz MW, von Kegler S, Steinmetz H, Markus HS, Sitzer M. Carotid intima-media thickening indicates a higher vascular risk across a wide age range: prospective data from the Carotid Atherosclerosis Progression Study (CAPS). Stroke. 2006;37:87-92.

104. Rosvall M, Janzon L, Berglund G, Engstrom G, Hedblad B. Incident coronary events and case fatality in relation to common carotid intima-media thickness. J Intern Med. 2005;257:430-437.

105. van der Meer IM, Bots ML, Hofman A, del Sol AI, van der Kuip DA, Witteman JC. Predictive value of noninvasive measures of atherosclerosis for incident myocardial infarction: the Rotterdam study. Circulation. 2004;109:1089-1094.

106. Murakami S, Otsuka K, Hotta N, Yamanaka G, Kubo Y, Matsuoka $\mathrm{O}$, et al. Common carotid intima-media thickness is predictive of all-cause and cardiovascular mortality in elderly community-dwelling people: longitudinal investigation for the longevity and aging in hokkaido county (LILAC) study. Biomed Pharmacother. 2005;59 Suppl 1:S49-S53.

107. Yeboah J, McClelland RL, Polonsky TS, Burke GL, Sibley CT, O'Leary D, et al. Comparison of novel risk markers for improvement in cardiovascular risk assessment in intermediate-risk individuals. JAMA. 2012;308:788-795.

108. Price JF, Tzoulaki I, Lee AJ, Fowkes FG. Ankle brachial index and intima media thickness predict cardiovascular events similarly and increased prediction when combined. J Clin Epidemiol. 2007;60:1067-1075.

109. Polak JF, Pencina MJ, Pencina KM, O'Donnell CJ, Wolf PA, D'Agostino RB Sr. Carotid-wall intima-media thickness and cardiovascular events. N Engl J Med. 2011;365:213-221.

110. Ali YS, Rembold KE, Weaver B, Wills MB, Tatar S, Ayers CR, et al. Prediction of major adverse cardiovascular events by age-normalized carotid intimal medial thickness. Atherosclerosis. 2006;187:186-190.

111. Anderson TJ, Charbonneau F, Title LM, Buithieu J, Rose MS, Conradson $\mathrm{H}$, et al. Microvascular function predicts cardiovascular events in primary prevention: long-term results from the Firefighters and Their Endothelium (FATE) study. Circulation. 2011;123:163-169.

112. Kitagawa K, Hougaku H, Yamagami H, Hashimoto H, Itoh T, Shimizu Y, et al. Carotid intima-media thickness and risk of cardiovascular events in high-risk patients. Results of the OSAKA follow-up study for carotid atherosclerosis 2 (OSACA2 study). Cerebrovasc Dis. 2007;24:35-42.

113. Johnsen SH, Mathiesen EB, Joakimsen O, Stensland E, Wilsgaard T, Lochen ML, et al. Carotid atherosclerosis is a stronger predictor of myocardial infarction in women than in men: a 6-year follow-up study of 6226 persons: the TROMS $\varnothing$ study. Stroke. 2007;38:2873-288o.

114. Chien KL, Su TC, Jeng JS, Hsu HC, Chang WT, Chen MF, et al. Carotid artery intima-media thickness, carotid plaque and coronary heart disease and stroke in Chinese. PLoS One. 2008;3:e3435.

115. Held C, Hjemdahl P, Eriksson SV, Bjorkander I, Forslund L, Rehnqvist N. Prognostic implications of intima-media thickness and plaques in the carotid and femoral arteries in patients with stable angina pectoris. Eur Heart J. 2001;22:62-72.

116. Cournot M, Taraszkiewicz D, Cambou JP, Galinier M, Boccalon $\mathrm{H}$, Hanaire-Broutin $\mathrm{H}$, et al. Additional prognostic value of physical examination, exercise testing, and arterial ultrasonography for coronary risk assessment in primary prevention. Am Heart J. 2009;158:845-851.

117. Prabhakaran S, Singh R, Zhou X, Ramas R, Sacco RL, Rundek T. Presence of calcified carotid plaque predicts vascular events: the Northern Manhattan study. Atherosclerosis. 2007;195:e197-e201.

118. Prati P, Tosetto A, Casaroli M, Bignamini A, Canciani L, Bornstein N, et al. Carotid plaque morphology improves stroke risk prediction: usefulness of a new ultrasonographic score. Cerebrovasc Dis. 2011;31:300-304.

119. Stork S, Feelders RA, van den Beld AW, Steyerberg EW, Savelkoul HF, Lamberts SW, et al. Prediction of mortality risk in the elderly. Am J Med. 2006;119:519-525.

120. Xie W, Wu Y, Wang W, Zhao D, Liang L, Wang M, et al. A longitudinal study of carotid plaque and risk of ischemic cardiovascular disease in the Chinese population. J Am Soc Echocardiogr. 2011;24:729-737.

121. Belcaro G, Nicolaides AN, Ramaswami G, Cesarone MR, De Sanctis M, Incandela L, et al. Carotid and femoral ultrasound morphology screening and cardiovascular events in low risk subjects: a 10-year follow-up study (the CAFES-CAVE study(1)). Atherosclerosis. 2001;156:379-387. 